\title{
The benefits of drug-eluting stents in the treatment of coronary artery disease
}

This article was published in the following Dove Press journal:

Research Reports in Clinical Cardiology

7 March 2016

Number of times this article has been viewed

\author{
Sarkis Kiramijyan' \\ Ming W Liu ${ }^{2}$ \\ 'Division of Cardiology, Department \\ of Medicine, Harbor-UCLA Medical \\ Center, Torrance, CA, USA; \\ ${ }^{2}$ Heart and Vascular Care Center, \\ White Memorial Medical Center, \\ Los Angeles, CA, USA
}

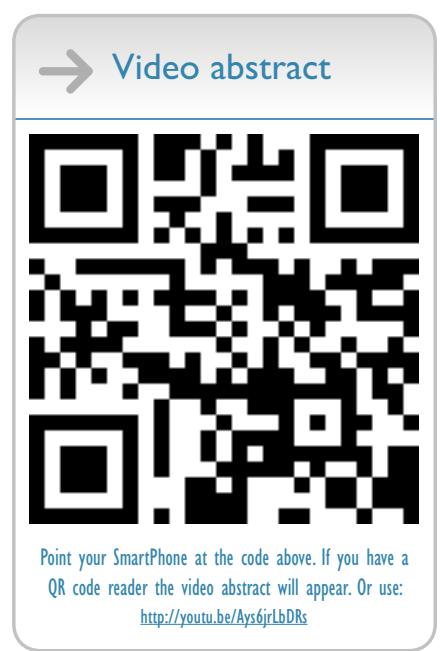

Correspondence: Ming W Liu Heart and Vascular Care Center, White Memorial Medical Center, 1720 Cesar E Chavez Avenue, Los Angeles, CA 90033, USA

$\mathrm{Tel}+\mathrm{I} 3232242100$

Fax + I 3232242106

Email mingwliu@gmail.com
Abstract: The advent of coronary stents has been a landmark development in the treatment of coronary artery disease with percutaneous coronary intervention. Initial percutaneous treatment using balloon angioplasty alone had limited clinical efficacy due to immediate vascular elastic recoil and dissection, in addition to late negative vascular remodeling and neointimal hyperplasia. With the introduction of coronary stents, initially bare-metal stents (BMS), the problems of dissection and negative remodeling due to injury in addition to vascular elastic recoil were eliminated; however, neointimal hyperplasia remained an ongoing obstacle in the long-term efficacy of stents. Neointimal hyperplasia resulted in in-stent restenosis in $20 \%-30 \%$ of cases after intervention with BMS, which led to high rates of target lesion revascularization. Subsequently, drug-eluting stents (DES) were introduced, which had the added advantage of releasing an anti-proliferative drug from the stent to reduce the neointimal proliferation, thus resulting in the reduction of the rates of in-stent restenosis. Although the first-generation DES had significantly improved outcomes over its predecessor, the BMS, several challenges including stent thrombosis and delayed endothelialization of the stent remained. The second-generation DES have been significantly improved over their first-generation predecessors in regard to efficacy and safety, ie, improved long-term outcomes and significant reductions in stent thrombosis. The duration of dual antiplatelet therapy after DES has also been studied extensively in multiple large trials. A newer generation of stents, including those with bioresorbable polymers, polymer-free, and fully bioresorbable scaffolds is still in the early stages of development. Lastly, the ongoing heated comparison in multiple trials regarding the use of coronary stents vs coronary artery bypass surgery for the treatment of complex/multi-vessel coronary disease continues to evolve.

Keywords: bare-metal stent, everolimus, zotarolimus, sirolimus, paclitaxel, percutaneous coronary intervention

\section{The beginning of percutaneous coronary intervention - conventional balloon angioplasty}

Percutaneous coronary intervention (PCI) has evolved tremendously since the first balloon coronary angioplasty was performed by Andreas Gruentzig in $1979 .{ }^{1}$ The introduction of balloon coronary angioplasty, also known as percutaneous transluminal coronary angioplasty, which subsequently has also been called 'plain old balloon angioplasty'(POBA), provided a historical breakthrough medical concept of using a non-surgical percutaneous form of revascularization as an alternative strategy to coronary artery bypass graft $(\mathrm{CABG})^{1}$ surgery. However, the immediate complications including acute vessel recoil and vascular dissection, in addition to long-term effects such as negative remodeling and intimal hyperplasia due to focal vascular injury, compromised its efficacy and 
safety. Angiographically significant restenosis occurred in approximately $40 \%$ of patients at 6 months, of whom, $50 \%-75 \%$ had recurrent ischemic symptoms. ${ }^{2}$ Therefore, approximately $20 \%-30 \%$ of patients appropriately required repeat revascularization of the index lesion within the first year after balloon angioplasty. Recurrent ischemic symptoms after 1 year were mostly due to new or progressive lesions. ${ }^{2-4}$ The pathophysiology of restenosis after balloon angioplasty was due to a combination of the following factors including: a) acute arterial recoil, b) coronary dissection, c) negative remodeling, and d) neointimal hyperplasia. Negative remodeling occurs gradually at the injured segment due to the contraction of the arterial wall during the healing process and is also related to the interaction of the endothelium with the blood flow. Neointimal hyperplasia occurs within weeks to months and is the proliferation and migration of smooth muscle cells (SMCs) from the tunica media into the tunica intima resulting in the encroachment onto the vascular lumen. ${ }^{5-8}$ The first three processes and/ or their sequelae were essentially completely controlled with the subsequent advent and use of bare-metal stents (BMS). However, the fourth factor, neointimal hyperplasia, continued to be a major challenge in the BMS era. ${ }^{9}$ Although neointimal hyperplasia is a major mechanism for restenosis after balloon angioplasty, it is the only mechanism for in-stent restenosis (ISR), excluding under-expansion of the stent. The pathophysiology of neointimal hyperplasia is therefore, very important and will be comprehensively discussed in the section of BMS.

\section{BMS as the next major evolutional technology in percutaneous intervention}

BMS was the first device used for coronary stenting and it was specifically developed to prevent acute artery closure due to vascular recoil or dissection following POBA. Subsequently, acute closure was reduced from $2 \%$ to $10 \%$ with POBA alone down to $<1 \%$ in the stent era and has resulted in a lower rate of peri-procedural myocardial infarction (MI). Further refinement of the BMS design, implantation techniques, and improved operator experience resulted in the rates of target lesion revascularization (TLR) being reduced to approximately $20 \%$ at 1 year after BMS implantation. ${ }^{10-12}$ The etiology of the relatively high rates of TLR was secondary to ISR due to the exaggerated neointimal proliferation. ${ }^{13}$

\section{Pathophysiology of neointimal proliferation - the major mechanism of ISR after stenting}

The mechanisms of neointimal hyperplasia after balloon angioplasty have been well described in the literature. ${ }^{13-15}$ The most commonly accepted model of neointimal hyperplasia is an adaptation of the "response-to-injury" model, which was initially described by Ross and Glomset in 1976. This model explains that the mechanical disruption of the endothelium by the PCI procedure is the initiating step in the neointimal hyperplasia mechanism. ${ }^{16,17}$ The initial compromise of a denuded endothelium and injury to the tunica intima and possibly tunica media due to the acute mechanical trauma of the PCI causes an initial inflammatory response in the vascular wall leading to platelet adhesion, activation and aggregation, and subsequent fibrin deposition and thrombus formation within the stent (thrombotic phase: days $0-3$ ). These microthrombi as well as the stretch injury of the vessel wall attract inflammatory cells such as macrophages and lymphocytes, which demarginate from the vascular space and also from the vasa vasorum (recruitment phase: days 3-8). Subsequently, these inflammatory cells stimulate the production of various local growth factors and cytokines, which activate the dormant G0 phase of the mitotic cycle of the SMCs in the intima media (Figure 1). This causes a subsequent remodeling process with significant inward migration of the SMCs to the interior of the implanted stent. Furthermore, the SMCs start to produce and deposit significant amounts of extracellular matrix (ECM) proteins, mostly proteoglycans, ${ }^{18}$ which lead to progressive narrowing and development of obstruction of the vessel lumen inside the index stent placement (proliferative phase: day 8 to healing). The hygroscopic quality of the proteoglycan matrix, when hardened, is relatively rigid and only transiently compressible, and may explain the difficulty with recoil in the setting of balloon angioplasty of ISR lesions. The exaggerated re-endothelialization is thought to play a major role in neointimal proliferation, and studies have reported variable patterns after coronary stent implantation..$^{15,19,20}$ Furthermore, it is yet unclear whether the new endothelium that covers the stent struts is adequately functional or not. ${ }^{21}$ However, given prior experiments performed in porcine animal models, it is fairly clear that the injury to the vascular wall caused by balloon-expandable stent implantation is greater and more sustained than that caused by POBA alone, ${ }^{22,23}$ and therefore, stent deployment actually induces more neointimal tissue growth than POBA alone. ${ }^{22,24-26}$ However, the magnitude of increase in lumen diameter made possible with a stent is greater than the increased neointimal growth. ${ }^{22}$ Therefore, the net increase in lumen diameter with the use of a stent improves the clinical outcomes when compared to POBA alone.

As the setting of the main process leading to ISR occurs locally at the site of injury of the vessel, a stent-based drug delivery system that can deliver a high concentration of an 


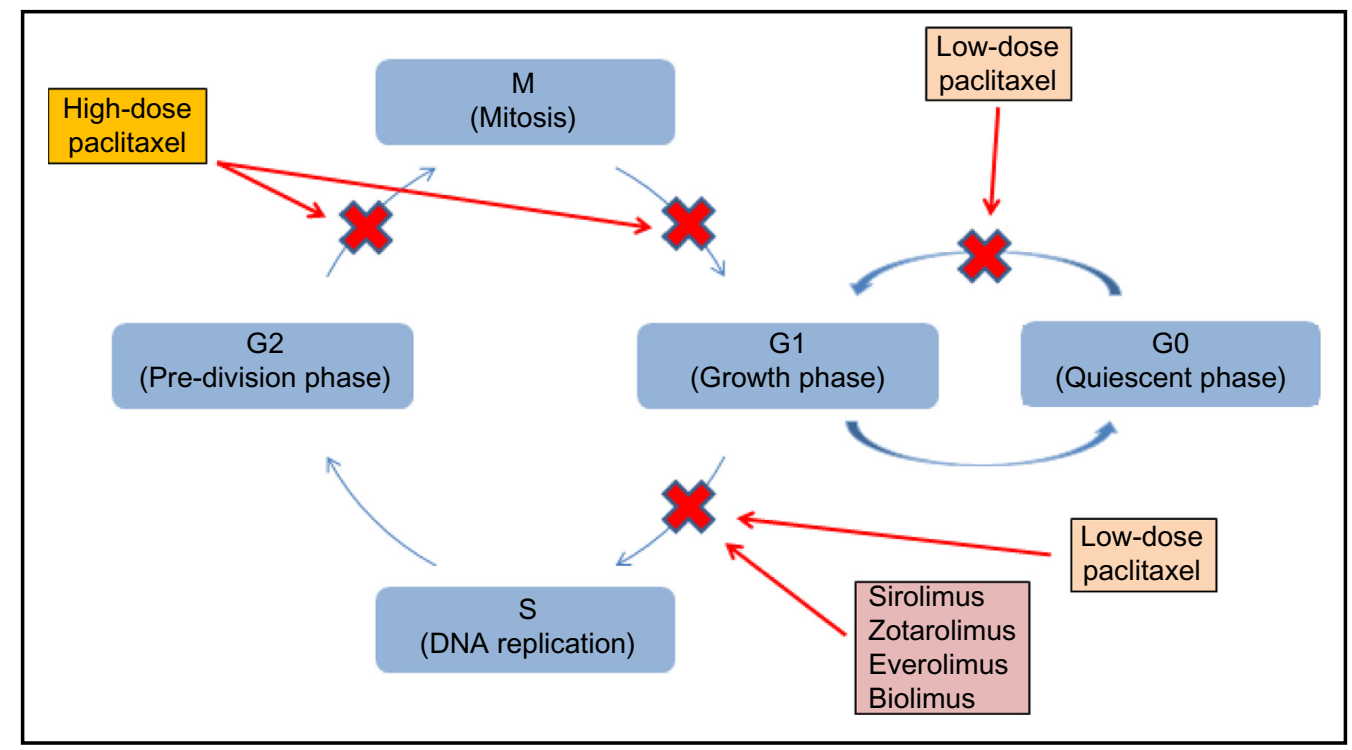

Figure I Endothelial cell cycle and inhibitory targets of anti-proliferative drugs.

Abbreviations: M, mitosis; GI, growth-I phase; S, DNA synthesis phase; G2, growth-2 phase; G0, resting phase.

effective anti-proliferative agent locally to attenuate the neointimal proliferation process without any systemic toxicity, would be the most logical solution to address ISR.

\section{Emergence of the first-generation drug-eluting stent devices as a breakthrough to minimize the restenosis \\ Drug-releasing mechanisms of DES}

The stent-based delivery of the anti-proliferative drug consists of three components: a metallic scaffold backbone, a drug carrying polymer that harbors the drug and allows it to diffuse into the vascular tissue in a controlled manner, and an effective anti-proliferative drug that would reduce the neointimal growth after injury of the vessel wall during stent implantation. The stent design relative to the drug distribution to the vessel wall is also an important factor in the delivery of the drug from the drug-eluting stent (DES). Prior published studies have demonstrated that a symmetric expansion of the stents with homogeneous distribution of struts is important for optimal drug distribution. ${ }^{27}$ Furthermore, a study with the use of intravascular ultrasound (IVUS) demonstrated that stents with non-uniform stent strut distributions led to greater gap distance between struts and therefore, resulted in more neointimal hyperplasia after sirolimus-eluting stent (SES) implantation. ${ }^{28}$

A large number of stent designs have been developed to date, although the most commonly used is the multi-cellular design. The multi-cellular design is categorized into "closedcell" and "open-cell" configurations. The closed-cell stent is designed to have uniform cell expansion and constant cell spacing when it is deployed in a curved coronary segment, which leads to a more uniform drug distribution. On the other hand, the open-cell stent is designed to have a larger surface coverage between the inner and outer curvatures in the curved coronary segments thus yielding improved conformability to curved surfaces at the expense of less uniform drug-release distribution. In summary, the optimal stent design for drug delivery includes a large stent surface coverage area, a small cell gap, and minimal strut deformation after deployment while maintaining high conformability, radial strength, and flexibility.

The pharmaceutical agent is usually bound to a matrix polymer, which functions as a drug reservoir to ensure that the drug is retained during the stent deployment process and subsequently controls the distribution of the drug. The type, composition, and design of the polymer coated on the stent frame dictate the drug-eluting kinetics of the DES. The release of the drug occurs in a sustained fashion over a period of weeks to months after implantation. The polymer coating can be categorized into organic vs inorganic, bioresorbable vs nonbioresorbable, synthetic vs naturally occurring substances. Usually a non-bioresorbable polymer coating is used in order to prevent triggering inflammatory processes. The most successfully tested DES have been coated with synthetic materials. The sirolimus stent has been coated with poly$n$-butyl methacrylate and polyethylene-vinyl acetate. The paclitaxel stent was coated with a triblock polymer matrix (poly lactide-co-e-capro-lactone copolymer) (Table 1). All naturally occurring organic materials are both bio- and hemocompatible and most have been known to elicit inflammatory 
responses in the vascular context, therefore have not been usually utilized as polymer material.

\section{Therapeutic agents to limit neointimal growth}

Many agents with anti-inflammatory and anti-proliferative properties have been tested as agents for DES. The general mechanism of action of most of the drugs tested is to stop the cell cycle progression of endothelial cells by inhibiting DNA synthesis $^{29}$ (Figure 1). Ultimately, the ideal drug to prevent restenosis exerts sufficient anti-proliferative effects while maintaining a wide enough therapeutic index at the site of implantation to allow eventual stent endothelialization and adequate vessel healing. In addition, it should have negligible or no systemic effects and also be compatible with the polymer and stent it is bonded with, in order to deliver an adequate dose uniformly to the target endothelium. ${ }^{30-32}$ Currently, several antiproliferative agents have been proven to be effective in preventing neointimal hyperplasia in human clinical trials (Table 1). Sirolimus (also called rapamycin), used in the SES system, is a fermentation product isolated from the bacterium, Streptomyces hygroscopicus. The drug is an immunosuppressant, which has been widely utilized for prevention of rejection solid organ transplantation. ${ }^{33}$ It is a lipophilic molecule; therefore, it can readily diffuse across the cell membranes of vascular SMCs and leukocytes when released from the stent surface, and ultimately blocks the cell cycle progression from G-1(growth) phase to S (DNA synthesis) phase of mitosis (Figure 1), and, thereby, limits SMC replication and proliferation. ${ }^{34-36}$ The first experience with the SES was published in 2001 demonstrating promising results with significant reduction in neointimal proliferation, ${ }^{37}$ which led to the development of the commercial Cypher stent. ${ }^{38}$ Paclitaxel, used in the paclitaxel-eluting stent (PES) system, is an antineoplastic agent originally isolated in the 1960s from the bark of the Pacific Yew Tree, Taxus brevifolia, which is found in the northwestern areas of the USA and Canada. It was approved by the US Food and Drug Administration (FDA) in the 1990s as a therapeutic agent for solid tumor cancers such as breast and ovarian cancer. ${ }^{39}$ It is also a lipophilic molecule, which can readily diffuse across cell membranes and has a potent stabilizing effect on microtubules by polymerizing the alpha units and subunits of tubulin and thereby enhancing microtubule assembly. This mechanism halts the progression of the cell cycle from growth-2 phase to G2 phase to M (mitosis) phase (Figure 1). ${ }^{40,41}$

\section{Clinical efficacy of first-generation DES}

DES were developed not only to act as vascular scaffolds in the diseased coronary artery but also to reduce the relatively high rates of ISR and subsequent TLR compared to its predecessor BMS, by becoming a drug delivery system. This led to the development of the modern day DES. Subsequent

Table I Drug-eluting coronary stents

\begin{tabular}{|c|c|c|c|c|c|c|c|c|}
\hline $\begin{array}{l}\text { Stent } \\
\text { type }\end{array}$ & Brand name & Drug & Manufacturer & $\begin{array}{l}\text { Scaffold } \\
\text { material }\end{array}$ & $\begin{array}{l}\text { Strut } \\
\text { thickness } \\
(\mu \mathrm{m})\end{array}$ & $\begin{array}{l}\text { Polymer } \\
\text { material }\end{array}$ & $\begin{array}{l}\text { Polymer } \\
\text { thickness } \\
(\mu \mathrm{m})\end{array}$ & $\begin{array}{l}\text { Drug elution } \\
\text { kinetics }\end{array}$ \\
\hline \multirow[t]{4}{*}{$\begin{array}{l}\text { First- } \\
\text { generation }\end{array}$} & Cypher & Sirolimus & Cordis//\&J & $\begin{array}{l}\text { Stainless } \\
\text { steel }\end{array}$ & 140 & PEVA, PBMA & 12.6 & $\begin{array}{l}80 \% \text { within the } \\
\text { first } 4 \text { weeks }\end{array}$ \\
\hline & Taxus Express & Paclitaxel & $\begin{array}{l}\text { Boston } \\
\text { Scientific }\end{array}$ & $\begin{array}{l}\text { Stainless } \\
\text { steel }\end{array}$ & 132 & SIBBS & 16 & $\begin{array}{l}10 \% \text { within the } \\
\text { first } 2 \text { weeks }\end{array}$ \\
\hline & Taxus Liberte & Paclitaxel & $\begin{array}{l}\text { Boston } \\
\text { Scientific }\end{array}$ & $\begin{array}{l}\text { Stainless } \\
\text { steel }\end{array}$ & 97 & SIBBS & 14 & $\begin{array}{l}10 \% \text { within the } \\
\text { first } 2 \text { weeks }\end{array}$ \\
\hline & Taxus lon & Paclitaxel & $\begin{array}{l}\text { Boston } \\
\text { Scientific }\end{array}$ & $\begin{array}{l}\text { Platinum- } \\
\text { chromium }\end{array}$ & 97 & SIBBS & 16 & $\begin{array}{l}10 \% \text { within the } \\
\text { first } 2 \text { weeks }\end{array}$ \\
\hline \multirow[t]{5}{*}{$\begin{array}{l}\text { Second- } \\
\text { generation }\end{array}$} & Endeavor & Zotarolimus & Medtronic & $\begin{array}{l}\text { Cobalt- } \\
\text { chromium }\end{array}$ & 91 & $\begin{array}{l}\text { MPC, LMA, HPMA, } \\
\text { 3-MPMA }\end{array}$ & 5.3 & $\begin{array}{l}95 \% \text { within the } \\
\text { first } 2 \text { weeks }\end{array}$ \\
\hline & Resolute & Zotarolimus & Medtronic & $\begin{array}{l}\text { Cobalt- } \\
\text { chromium }\end{array}$ & 91 & $\begin{array}{l}\text { PBMA, PHMA, } \\
\text { PVP, PVA (Biolynx) }\end{array}$ & 5.6 & $\begin{array}{l}85 \% \text { within the } \\
\text { first } 8 \text { weeks }\end{array}$ \\
\hline & $\begin{array}{l}\text { Xience (V, Prime, } \\
\text { Xpedition, Alpine) }\end{array}$ & Everolimus & $\begin{array}{l}\text { Abbott } \\
\text { Vascular }\end{array}$ & $\begin{array}{l}\text { Cobalt- } \\
\text { chromium }\end{array}$ & 81 & PBMA, PVDF-HFP & 7.6 & $\begin{array}{l}80 \% \text { within the } \\
\text { first } 4 \text { weeks }\end{array}$ \\
\hline & Promus & Everolimus & $\begin{array}{l}\text { Boston } \\
\text { Scientific }\end{array}$ & $\begin{array}{l}\text { Cobalt- } \\
\text { chromium }\end{array}$ & 81 & PBMA, PVDF-HFP & 7.6 & $\begin{array}{l}80 \% \text { within the } \\
\text { first } 4 \text { weeks }\end{array}$ \\
\hline & $\begin{array}{l}\text { Promus (Element, } \\
\text { Premier) }\end{array}$ & Everolimus & $\begin{array}{l}\text { Boston } \\
\text { Scientific }\end{array}$ & $\begin{array}{l}\text { Platinum- } \\
\text { chromium }\end{array}$ & 81 & PBMA, PVDF-HFP & 7.6 & $\begin{array}{l}80 \% \text { within the } \\
\text { first } 4 \text { weeks }\end{array}$ \\
\hline
\end{tabular}

Abbreviations: PBMA, poly-n-butyl methacrylate; PEVA, poly-ethylene-co-vinyl acetate; SIBBS, styrene-b-isobutylene-b-styrene; MPC, methacryloyloxyethyl phosphorylcholine; LMA, lauryl methacrylate; HPMA, hydroxypropyl methacrylate; 3-MPMA, 3-trimethoxysilyl-propyl methacrylate; PHMA, poly-hexyl methacrylate; PVP, polyvinylpyrrolidone; PVA, polyvinyl acetate; PVDF-HFP, copolymer of vinylidene fluoride and hexafluoro-propylene. 
clinical trials have confirmed a reduction of as much as $50 \%-70 \%$ in TLR by DES compared to BMS with levels of ISR markedly reduced to $5 \%-8 \%$ range with the early firstgeneration DES trials. ${ }^{42,43}$

In clinical trials, DES outperforms BMS with regard to the efficacy endpoint of the need for repeat revascularization. The studies do not demonstrate a difference in long-term mortality. The different types of stents are presented in a table format (Table 1). Restenosis and the need for TLR usually occur within the first year after stent placement. It is within the first year that DES are superior to BMS. Verylate ISR (after 1 year) has been documented with all types of coronary stents. The rate is approximately $1 \%-2 \%$ per year and is similar between first- and second-generation DES and BMS. ${ }^{44} 47$

Several landmark clinical trials demonstrated the efficacy of SES in the reduction of ISR compared to BMS. The RAVEL Trial ${ }^{38}$ and the SIRIUS Trial ${ }^{48,49}$ both demonstrated that the SES was significantly superior to BMS in reducing ISR and TLR. Furthermore, subsequent studies demonstrated that SES reduced ISR and TLR specifically in patients with diabetes and MI. ${ }^{50,51}$ The long-term 5-year follow-up of the SIRIUS trial ${ }^{44}$ demonstrated the sustained benefit of the SES over the BMS with target vessel revascularization (TVR) at $9.4 \%$ vs $24.2 \%, P<0.001$, respectively. However, overall there were no significant reductions of the clinical endpoints of death or MI.

The PES was largely evaluated with the multiple TAXUS trials, ${ }^{43,45,52-54}$ which demonstrated significant reductions of ISR and TVR in the PES vs BMS. Long-term 5-year data of the TAXUS-IV trial also confirmed the efficacy and safety of the PES over BMS, in non-complex lesions, with sustained long-term results, including improved TVR ( $16.9 \%$ vs $27.4 \% ; P<0.0001)$, and improved major adverse cardiac events (MACE) (composite of cardiac death, myocardial infarction, or TLR) $(24.0 \%$ vs $32.8 \%, P=0.0001)$ of PES vs BMS, respectively. ${ }^{45}$ The TAXUS V and VI trials also demonstrated safety of the PES in high-risk, long and complex coronary lesions, confirming its safety and efficacy for real-world practice. ${ }^{55,56}$

After the establishment of the superiority of the firstgeneration DES over their BMS predecessors, preliminary head-to-head data published in 2005 demonstrated that SES may be superior to PES based on reductions in MACE, which were predominantly driven by decreases in TLR at a 9-month follow-up period. ${ }^{57}$ On the other hand, late outcomes at 5-year follow-up demonstrated that SES and PES had similar outcomes in regards to cardiac events, MI, TLR, ISR profiles and very-late stent thrombosis (ST) rates. ${ }^{58}$ The largest and most comprehensive meta-analysis was published by Stettler et al ${ }^{59}$ in 2007, which included 38 randomized trials and over 18,000 patients who had undergone PCI with a first-generation DES or BMS, excluding left main disease, chronic total occlusions, and bifurcation lesions. It demonstrated an overall reduction in TLR, increased late-ST (30 days to 1 year), and no difference in mortality at up to 4 years of follow-up in the first-generation DES vs BMS, respectively.

\section{The shortcomings of first-generation DES: late and very-late ST as well as a late catch-up phenomenon}

The initial reported randomized controlled trials of firstgeneration DES as described earlier did not result in any safety concerns; $;^{42,43}$ however, later reports of four cases of angiographically confirmed late ST after SES and PES caused concerns about the possibility of late and very-late ST associated with first-generation DES. ${ }^{60,61}$ Subsequently, a report which included pooled data from two high-volume European centers with a total $\mathrm{N}=8,146$ patients demonstrated a cumulative incidence of definite and probable ST of $5.7 \%$ after 4 years without signs of a plateau and in a setting of a steady accrual of late definite ST at a rate of $0.44 \%-0.63 \%$ per year without plateau after 4 years of follow-up. ${ }^{62} \mathrm{~A}$ later, very concerning, meta-analysis comparing first-generation DES vs BMS suggested a higher risk of death and MI with first-generation DES vs BMS. ${ }^{63}$ Other reports from realworld studies demonstrated an elevated risk of very-late ST and $\mathrm{MI}$ in patients treated with first-generation DES after stopping dual antiplatelet therapy (DAPT). ${ }^{62,64}$ Animal and human autopsy data indicated that the first-generation DES, when compared to BMS, significantly compromised the healing process of the injured arterial wall with evidence of chronic incomplete re-endothelialization and persistence of fibrin deposition, and therefore, concluded that this was the principal etiology of late and very-late ST. ${ }^{65}$ Other metaanalyses demonstrated no significant differences in the risk of mortality or MI, but did show a significantly increased risk of very-late ST with both SES and PES compared to BMS. ${ }^{66-69}$ These reports prompted cardiac societies and the FDA to recommend lengthening the guideline requirement of DAPT after DES from the previous 3-6 months (per study in the pivotal FDA approval trials of first-generation DES) to an arbitrary minimum of 1 year post-stent implantation. ${ }^{64,70-73}$

Furthermore, the SIRTAX-LATE trial ${ }^{58}$ suggested that there may be a "catch-up" occurrence (late lumen loss) with both SES and PES after long-term follow-up. Among patients 
undergoing paired angiography at 8 months and 5 years, delayed lumen loss amounted to $0.37 \pm 0.73 \mathrm{~mm}$ for SES and $0.29 \pm 0.59$ $\mathrm{mm}$ for PES $(P=0.32)$. The overall rate of definite ST was $4.6 \%$ for SES and $4.1 \%$ for PES ( $P=0.74$ ), and very-late definite ST occurred at an annual rate of $0.65 \%$. The ongoing increase in late lumen loss in addition to the continuous risk of very-late ST suggested that vascular healing remained incomplete at up to 5 years after implantation of a first-generation DES.

\section{Second-generation DES as current standard therapy in $\mathrm{PCI}$ Development of the second- generation DES}

The ongoing safety concerns about late and very-late ST with first-generation DES $^{64}$ sparked the development of newer stents with more biocompatible polymers, advanced stent platforms, and use of different drugs, with the resultant development of second-generation DES. In the setting of incomplete re-endothelialization and persistent fibrin deposition being the major causes of late ST, ${ }^{65}$ the objective was to develop a stent device that would promote early re-endothelialization.

Incomplete re-endothelialization can be secondary to two causes: 1) the anti-proliferative effects of the drug released from the polymer of the stent, which attenuates the endothelial healing response and 2) the intrinsic deficiency of the vascular endothelial progenitor cells, which is associated with poor outcomes. ${ }^{74,75}$ It is important to note that BMS can achieve complete re-endothelialization by 6-7 months post-PCI, on the other hand, first-generation DES may not be fully re-endothelialized at up to 40 months post-PCI. ${ }^{76}$ In addition, the polymer matrix itself has been shown to induce local inflammation, which leads to negative remodeling and compromised vascular healing and re-endothelialization. ${ }^{76,77}$ The second-generation DES with their thinner and more biocompatible polymers (Table 1) have been shown to have reduced $\mathrm{ST}$ rates and better re-endothelialization than the first-generation DES. ${ }^{78,79}$ Moreover, stent construction and design has also been shown to play an important role in the re-endothelialization of the stent struts as studies have demonstrated that thinner struts reduce the late-luminal loss. ${ }^{80}$ Therefore, the second-generation DES are constructed with thinner stent struts (Table 1). In fact, optical coherence tomography studies of the second-generation stent - zotarolimus-eluting stent (ZES) demonstrated that thinner stent struts reduces malapposition and improves re-endothelialization, thus reducing the risk of subsequent
ST. ${ }^{81,82}$ Second-generation DES were developed with advanced designs and features, including thinner strut design, improved flexibility and deliverability, and a platform using either a cobalt-chromium $(\mathrm{CoCr})$ or a platinum-chromium (PtCr) metal, more biocompatible polymers, thinner polymer layers, and accelerated kinetics of drug elution to promote faster re-endothelialization (Table 1). Everolimus, similar to sirolimus, is an anti-proliferative agent demonstrated to inhibit SMC proliferation in vitro and inhibit vascular neointimal hyperplasia in animal transplant models ${ }^{83}$ (Figure 1). Given its effective cytotoxic properties, it was deemed to be of benefit in the pursuit against ISR, subsequently prompting the development of the Xience-V CoCR-everolimus-eluting stent (EES) and the Promus CoCr-EES as initial secondgeneration DES.

The mechanisms of the CoCr-EES that lead to better outcomes is likely multifactorial and include (Table 1): the more rapid and complete endothelialization of the struts, the different scaffold alloy, architecture, and thinner ( 81 or $91 \mu \mathrm{m})$ malleable struts, low polymer load and drug type, and the drug-release kinetics in addition to the thromboresistant fluoro-copolymer, all contributing to the reduced rates of ST. ${ }^{68,84}$ The utilization of fluoro-copolymer coated stents has been demonstrated to be safer than BMS counterparts with lower rates of ST and platelet deposition. ${ }^{68,84}$ Two versions of the EES are currently commercially available in the USA: the CoCr-EES and PtCr-EES frame materials. Zotarolimus is a derivative drug of sirolimus with a similar anti-proliferative mechanism of action in the cell cycle although with enhanced lipophilic properties (Figure 1). The ZES is made by Medtronic, Inc. and is produced in two models, the older Endeavor (E-ZES) and the newer Resolute (R-ZES). Both stents are built on a CoCr platform. At the 9-month followup period, in-stent late lumen loss was $0.22 \mathrm{~mm}$ with the newer R-ZES, which was significantly lower than that previously observed in the older version E-ZES. ${ }^{85}$

\section{Superiority of second-generation DES over first-generation DES}

SPIRIT III randomly assigned 1,002 patients with de novo coronary artery lesions to either EES or PES in a 2:1 fashion. ${ }^{86}$ The EES was superior to PES regarding the primary endpoint of angiographic in-segment late loss at 8 months ( 0.14 vs 0.28 $\mathrm{mm}, P \leq 0.004)$. At the 2 -year follow-up, the endpoint of target vessel failure (composite of cardiac death, target vessel MI, or ischemia-driven TVR) demonstrated significantly lower rates with the EES vs PES (10.7\% vs $14.4 \%, P=0.04$ ), and the endpoint of MACE was significantly lower with EES vs PES (7.3\% vs $12.8 \%, P=0.004) .{ }^{87}$ The SPIRIT IV trial randomly 
assigned 3,687 patients with more complex coronary disease in a $2: 1$ fashion to EES or PES. ${ }^{88}$ The primary endpoint of target lesion failure (TLF) (composite of cardiac death, target vessel MI, ischemia-driven TLR) at 2 years was significantly lower in the EES vs the PES group ( $6.9 \%$ vs $9.9 \%, P=0.003) .{ }^{89}$ The COMPARE trial randomly assigned 1,800 all-comer, realworld patients to EES or PES. The rate of the primary endpoint (composite of death, MI, and TVR) was significantly less with EES vs PES at 12 months (6\% vs $9 \%)^{90}$ and at 2 years followup $(9.0 \%$ vs $13.7 \%),{ }^{91}$ thus providing additional support for the superior performance of the EES over its first-generation predecessor PES (Table 2).

\section{Comparable clinical trials among the three current second-generation DES available}

The RESOLUTE All Comers Trial randomly assigned 2,292 patients undergoing PCI with either R-ZES or Xience$\mathrm{V}$ EES including a primary endpoint of TLF within 12 months, which demonstrated similar results with R-ZES vs Xience-V EES (8.2\% vs 8.3\%, $P<0.001)$ for non-inferiority. ${ }^{92-94}$ At 2 and 4 years follow-up, there was no significant difference between the R-ZES and EES groups in either the composite patient-related outcome or the stent-related outcome. The rate of definite or probable ST was not significantly different between R-ZES and EES at 1 year $(2.3 \%$ vs $1.5 \%$, respectively, $P=0.17$ ) or 4 years $(2.3 \%$ vs $1.6 \%$, respectively, $P=0.23) .{ }^{92-94}$ Furthermore, the DUTCH PEERS trial randomized 1,811 all-comer patients with a total of 2,371, both stable and unstable target lesions, to the newly designed, more flexible, Resolute Integrity-ZES vs the PtCr-EES. ${ }^{95}$ The primary combined endpoint of target vessel failure at 1 year occurred with similar rates in the R-ZES vs PtCr-EES groups (6\% and $5 \%$, respectively) $)^{95}$ (Table 3 ).
These two versions of the EES were found to have similar efficacy and safety endpoints in the PLATINUM trial, which randomly assigned 1,530 patients with one or two de novo native coronary lesions to CoCr-EES or PtCrEES. ${ }^{96}$ The novel PtCr-EES was found to be non-inferior to the CoCr-EES with 12-month rates of TLF (a composite of target vessel-related cardiac death, target vessel-related MI, or ischemia-driven TLR) at $2.9 \%$ vs $3.4 \%$ for the CoCr-EES vs PtCr-EES, respectively. ${ }^{96}$ Subsequently, again at the 4-year follow-up, no significant differences were found. ${ }^{97}$

\section{Network meta-analyses of clinical trials comparing first- and second- generation DES and BMS}

Bangalore et $\mathrm{a}^{18}$ published the largest network meta-analysis comparing the various types of stent designs among approximately 118,000 patients at $\leq 1$ year and long-term endpoints with a mixed-treatment comparison. TLR for SES, EES, and R-ZES were similar and had lower rates than PES or E-ZES. With regard to the risk of $\mathrm{MI}$, there was a reduction in all DES except PES vs BMS. With regard to the risk of definite or probable ST, EES had the lowest risk of any DES, and therefore appeared to be the safest stent. In another network meta-analysis, Palmerini et al included 50,844 patients in 49 trials. ${ }^{99}$ The ST rate is the lowest with the CoCr-EES compared to all the other first-generation DES and BMS both at 1 and 2 years follow-up. PtCr-EES also had a lower rate of ST compared to first-generation DES or BMS. In a similar, more recent meta-analysis, which included a total of 52,158 randomized patients, ${ }^{100}$ it was demonstrated that after a median follow-up of 3.8 years, all DES demonstrated superior efficacy compared with BMS in terms of revascularization and MI. In addition, among DES, the currently utilized second-generation devices have largely equivalent

Table 2 Clinical trials demonstrating superiority of second-generation DES over first-generation DES

\begin{tabular}{|c|c|c|c|c|c|}
\hline Clinical trials & Stent compared & Efficacy endpoint* & $\begin{array}{l}\text { Safety endpoint } \\
\text { stent thrombosis* }\end{array}$ & $\begin{array}{l}\text { Follow-up } \\
\text { duration }\end{array}$ & Patient number \\
\hline SPIRIT III & Xience $\mathrm{V}$ vs Taxus Express 2 & $\begin{array}{l}\text { TVF: } 10.7 \% \text { vs } 15.4 \% \\
\text { MACE: } 7.3 \% \text { vs } 12.8 \%\end{array}$ & $1.0 \%$ vs $1.7 \%$ & 2 years & 1,002 \\
\hline SPIRIT IV ${ }^{89}$ & Xience $\mathrm{V}$ vs Taxus Express 2 & $\begin{array}{l}\text { TLF: } 6.9 \% \text { vs } 9.9 \% \\
\text { MACE: } 7.1 \% \text { vs } 10.1 \%\end{array}$ & $0.4 \%$ vs $1.2 \%$ & 2 years & 3,687 \\
\hline COMPARE $^{91}$ & Xience V vs Taxus Liberte & $\begin{array}{l}\text { TVR: } 3.2 \% \text { vs } 8.0 \% \\
\text { MACE: } 7.4 \% \text { vs } 11.3 \%\end{array}$ & $0.9 \%$ vs $3.9 \%$ & 2 years & $\mathrm{I}, 795$ \\
\hline SCAAR Registry ${ }^{47}$ & Second-gen vs first-gen DES & $\begin{array}{l}\text { TLR: } 3.1 \% \text { vs } 4.9 \% \\
\text { Death: } 1.9 \% \text { vs } 3.4 \%\end{array}$ & $0.6 \%$ vs $1.3 \%$ & 2 years & $\begin{array}{l}29,753 \text { (excluding } \\
\text { BMS patients) }\end{array}$ \\
\hline
\end{tabular}

Notes: Second-generation DES include Endeavor Resolute, Xience V, Xience Prime, Promus, Promus Element. First-generation DES include Cypher, Cypher Select, Taxus Express and Taxus Liberte. *All comparisons in efficacy and safety endpoints were clinically significant.

Abbreviations: DES, drug-eluting stents; gen, generation; TLR, target lesion revascularization; MACE, major adverse cardiac events (composite of cardiac death, myocardial infarction, or TLR); TLF, target lesion failure (composite of cardiac death, target vessel myocardial infarction, or ischemia-driven TLR); TVR, target vessel revascularization; TVF, target vessel failure (composite of cardiac death, target vessel myocardial infarction, or ischemia-driven TVR); BMS, bare-metal stents. 
Table 3 Equivalency of outcomes in clinical trials among the current three second-generation DES

\begin{tabular}{|c|c|c|c|c|c|}
\hline Trial name & Stent compared & Efficacy endpoint* & $\begin{array}{l}\text { Safety endpoint } \\
\text { stent thrombosis* }\end{array}$ & Follow-up & $\begin{array}{l}\text { Patient } \\
\text { number }\end{array}$ \\
\hline PLATINUM ${ }^{96}$ & $\begin{array}{l}\text { Promus Element vs } \\
\text { Xience V }\end{array}$ & $\begin{array}{l}\text { TLF: } 3.4 \% \text { vs } 2.9 \% \\
\text { Cardiac death/MI: } 2.0 \% \text { vs } 2.5 \%\end{array}$ & $0.4 \%$ vs $0.4 \%$ & I year & 1,530 \\
\hline PLATINUM ${ }^{97}$ & $\begin{array}{l}\text { Promus Element vs } \\
\text { Xience V }\end{array}$ & $\begin{array}{l}\text { TLF: } 7.4 \% \text { vs } 8.5 \% \\
\text { All-cause death: } 5.0 \% \text { vs } 6.0 \% \\
\text { MI: } 2.6 \% \text { vs } 2.8 \%\end{array}$ & $0.7 \%$ vs $0.7 \%$ & 4 years & 1,530 \\
\hline $\begin{array}{l}\text { RESOLUTE All } \\
\text { Comers }^{93}\end{array}$ & Resolute vs Xience $\mathrm{V}$ & $\begin{array}{l}\text { TVR: } 10.0 \% \text { vs } 9.1 \% \\
\text { MACE: } 12.5 \% \text { vs } 12.9 \%\end{array}$ & $1.9 \%$ vs $1.0 \%$ & 2 years & 2,292 \\
\hline DUTCH PEERS 95 & $\begin{array}{l}\text { Resolute Integrity vs } \\
\text { Promus Element }\end{array}$ & $\begin{array}{l}\text { TLR: } 3 \% \text { vs } 3 \% \\
\text { TVF: } 6 \% \text { vs } 5 \%\end{array}$ & $1 \%$ vs $2 \%$ & I year & 1,811 \\
\hline
\end{tabular}

Notes: Promus Element $=$ PtCr-EES (platinum-chromium everolimus-eluting stent); Xience $\mathrm{V}=\mathrm{CoCr}$-EES (cobalt-chromium everolimus-eluting stent); Resolute $+/-$ Integrity = zotarolimus-eluting stent. *All comparisons in efficacy and safety endpoints were clinically non-significant.

Abbreviations: DES, drug-eluting stents; TLR, target lesion revascularization; MACE, major adverse cardiac events (composite of cardiac death, myocardial infarction, or TLR); TLF, target lesion failure (composite of cardiac death, target vessel myocardial infarction, or ischemia-driven TLR); TVR, target vessel revascularization; TVF, target vessel failure (composite of cardiac death, target vessel MI, or ischemia-driven TVR); MI, myocardial infarction.

outcomes and have substantially improved long-term safety of lower ST and efficacy of lower TVR and MI compared with the first-generation DES and BMS.

\section{The dilemma of optimal duration of DAPT: a balance of reducing ischemia vs increased risk of bleeding The current standard duration of DAPT after DES implantation recommendation}

The American College of Cardiology/American Heart Association guidelines 2011 recommend a 12-month duration of DAPT in patients undergoing PCI with DES for stable coronary artery disease at low bleeding risk. ${ }^{70}$ The 2013 European Society of Cardiology guidelines on stable coronary artery disease $^{101}$ recommend a duration of 6 to 12 months of DAPT in patients undergoing PCI with DES, but more recently recommended a DAPT duration of 6 months after DES implantation in patients with stable coronary artery disease (Class I, Level B) ${ }^{102}$ and call for individualized treatment according to bleeding and thrombotic risk. The recent DAPT trial randomly ${ }^{103}$ assigned 9,961 patients who had undergone PCI with a first or second-generation DES, and who had subsequently undergone successful treatment with 12 months of aspirin and a $\mathrm{P} 2 \mathrm{Y}_{12}$ receptor blocker (either clopidogrel or prasugrel), to either continue receiving the $\mathrm{P} 2 \mathrm{Y}_{12}$ receptor blocker or a placebo for an additional 18 months with all patients continuing aspirin therapy. ${ }^{103}$ The rates for each of the co-primary efficacy endpoints of ST and MACE (a composite of death, $\mathrm{MI}$, or stroke) during the period from 12 to 30 months were lower with continued $\mathrm{P} 2 \mathrm{Y}_{12}$ therapy $(0.4 \%$ vs $1.4 \%, P<0.001$ for ST and $4.3 \%$ vs $5.9 \%, P<0.001$ for MACE). However, the rate of the primary safety endpoint ie, moderate or severe bleeding was increased $(2.5 \%$ vs $1.6 \%, P=0.001)$ with the continued $\mathrm{P} 2 \mathrm{Y}_{12}$ therapy group.

\section{The results of current trials comparing short duration, standard duration, and long duration of DAPT}

Up to date, there have been ten randomized trials with five trials comparing shorter duration (3-6 months) vs standard duration (12 months), ${ }^{104-108}$ and the other five trials comparing shorter duration (6-12 months) vs long duration (>24 months). ${ }^{103,109-112}$ However, except for one trial (ITALIC), which used only second-generation DES, ${ }^{109}$ the other nine trials used a combination of first and second-generation DES with or without BMS. In all but one trial, the results demonstrated that prolonged ( $>24$ months) DAPT is associated with reduced ischemic events. Most of the trials demonstrated that a shortened duration vs standard duration or that a standard duration vs long duration were equivalent in clinical outcomes. However, a recent meta-analysis based on these ten randomized controlled trials ${ }^{113}$ concluded that the rate of ST is higher and statistically significant with shorter duration than longer duration $(0.9 \%$ vs $0.5 \%, P=0.001)$; major bleeding events are less with shorter duration than long duration (1.2\% vs $1.9 \%$, $P<0.001$ ), (Table 4). Nonetheless, these conclusions should be interpreted with great caution. As discussed earlier, firstgeneration DES are associated with higher rates of ST and lower efficacy compared with second-generation DES. A total of nine out of these ten clinical trials have utilized a mixture of first-generation DES, second-generation DES, and BMS. ST is a very rare event and the vast majority of the trials to date have not been powered enough to reveal an accurate difference. Therefore, the endpoint of these trials usually 
Table 4 Randomized trials of DAPT comparing different durations of therapy after stenting

\begin{tabular}{|c|c|c|c|c|c|c|c|}
\hline Trial name & Stent types & $\begin{array}{l}\text { Patient } \\
\text { number }\end{array}$ & $\begin{array}{l}\text { Duration } \\
\text { compared } \\
\text { (months) }\end{array}$ & Ischemia $^{\mathrm{a}}$ & Bleeding $^{\mathrm{b}}$ & Equivalency ${ }^{c}$ & $\begin{array}{l}\text { Follow-up } \\
\text { duration }\end{array}$ \\
\hline \multicolumn{8}{|c|}{ Short duration DAPT } \\
\hline ISAR-SAFE 104 & EES and R-ZES $60 \%$ & 4,000 & 6 vs 12 & $\begin{array}{l}\text { Death/MI/Stroke/ST/Bleeding: } \\
\text { I. } 5 \% \text { vs } 1.6 \% \\
\text { ST: } 0.3 \% \text { vs } 0.2 \%\end{array}$ & $0.2 \%$ vs $0.3 \%$ & Yes & 9 months \\
\hline EXCELLENT 105 & CoCr EES 75\% & $\mathrm{I}, 443$ & 6 vs 12 & $\begin{array}{l}\text { Death/MI: } 2.4 \% \text { vs } 1.9 \% \\
\text { TLR: } 2.4 \% \text { vs } 2.6 \% \\
\text { ST: } 0.9 \% \text { vs } 0.1 \%\end{array}$ & $0.3 \%$ vs $0.6 \%$ & Yes & I year \\
\hline OPTIMIZE 106 & E-ZES $100 \%$ & 3,119 & 3 vs 12 & $\begin{array}{l}\text { Death/MI/ST: } 4.7 \% \text { vs } 4.2 \% \\
\text { TLR: } 3.2 \% \text { vs } 3.5 \% \\
\text { ST: } 0.8 \% \text { vs } 0.8 \%\end{array}$ & $0.6 \%$ vs $0.9 \%$ & Yes & I year \\
\hline RESET $^{107}$ & $\begin{array}{l}\text { E-ZES } 50 \% \text {, } \\
\text { R-ZES } 20 \% \text {, EES I5\%, } \\
\text { SES I5\% }\end{array}$ & 2,117 & 3 vs 12 & $\begin{array}{l}\text { Death/MI/ST: } 0.8 \% \text { vs } 1.3 \% \\
\text { ST: } 0.2 \% \text { vs } 0.3 \% \\
\text { TLR: } 3.9 \% \text { vs } 3.7 \%\end{array}$ & $0.2 \%$ vs $0.6 \%$ & Yes & I year \\
\hline SECURITY108 & $\begin{array}{l}\text { Second-generation } \\
\text { DES } 70 \%\end{array}$ & 1,399 & 6 vs 12 & $\begin{array}{l}\text { Death/MI/ST/Bleeding: } \\
4.5 \% \text { vs } 3.7 \% \\
\text { ST: } 0.4 \% \text { vs } 0.4 \%\end{array}$ & $0.2 \%$ vs $0.3 \%$ & Yes & I year \\
\hline \multicolumn{8}{|c|}{ Long duration DAPT } \\
\hline ITALIC 109 & Xience only & 2,031 & 6 vs 24 & $\begin{array}{l}\text { Death/MI/Stroke/Bleeding: } \\
\text { I. } 6 \% \text { vs } 1.5 \% \\
\text { ST: } 0.3 \% \text { vs } 0 \%\end{array}$ & $0 \%$ vs $0.3 \%$ & Yes & I year \\
\hline PRODIGY 110 & $\begin{array}{l}\text { BMS 25\%, Cypher } \\
25 \% \text {, Taxus } 25 \% \text {, } \\
\text { Endeavor } 25 \%\end{array}$ & 2,013 & 6 vs 24 & $\begin{array}{l}\text { Death/MI/Stroke: } 10.0 \% \text { vs } \\
10.1 \% \\
\text { ST: } 1.5 \% \text { vs } 1.3 \%\end{array}$ & $3.5 \%$ vs $7.4 \%$ & $\begin{array}{l}\text { Increased } \\
\text { bleeding }\end{array}$ & 2 years \\
\hline DAPT 103 & $\begin{array}{l}\text { Xience } 47 \% \text {, Taxus } \\
27 \% \text {, Endeavor } 13 \% \text {, } \\
\text { Cypher } 11 \%\end{array}$ & $9,961 *$ & 12 vs 30 & $\begin{array}{l}\text { Death/MI/Stroke: } 5.9 \% \text { vs } 4.3 \% \\
\text { ST: I. } 4 \% \text { vs } 0.4 \%\end{array}$ & $1.6 \%$ vs $2.5 \%$ & $\begin{array}{l}\text { Increased } \\
\text { bleeding reduced } \\
\text { ischemia }\end{array}$ & I year \\
\hline $\begin{array}{l}\text { ARCTIC- } \\
\text { Interruption"II }\end{array}$ & $\begin{array}{l}\text { First-generation } \\
\text { DES } 40 \% \text {, Second- } \\
\text { generation DES } 60 \%\end{array}$ & 1,259 & 12 vs $18-30$ & $\begin{array}{l}\text { Death/MI/Stroke } \\
\text { /Urgent PCI: } 4.0 \% \text { vs } 4.0 \% \\
\text { ST: I } \% \text { vs } 0 \%\end{array}$ & $<0.5 \%$ vs $1 \%$ & Yes & I year \\
\hline DES-LATE $/ 12$ & $\begin{array}{l}\text { Cypher } 40 \% \text {, Taxus } \\
20 \% \text {, Endeavor } 20 \%\end{array}$ & 5,045 & 12 vs 24 & $\begin{array}{l}\text { Death/MI/Stroke: } 2.4 \% \text { vs } 2.6 \% \\
\text { TLR: } 2.8 \% \text { vs } 3.5 \% \\
\text { ST: } 0.5 \% \text { vs } 0.3 \%\end{array}$ & I.1\% vs $1.4 \%$ & Yes & 2 years \\
\hline
\end{tabular}

Notes: alschemic: endpoint of studies (some studies included bleeding events); bbleeding: major bleeding events (definitions vary among studies); 'conclusion of studies whether the two strategies achieved similar outcomes; *35\% of patients in DAPT trial were on prasugrel.

Abbreviations: DAPT, dual antiplatelet therapy; DES, drug-eluting stents; TLR, target lesion revascularization; MI, myocardial infarction; ST, stent thrombosis; EES, everolimus-eluting stent; CoCr, cobalt-chromium; E-ZES, Endeavor zotarolimus-eluting stent; R-ZES, Resolute zotarolimus-eluting stent; SES, sirolimus-eluting stent; BMS, bare-metal stents; $\mathrm{PCl}$, percutaneous coronary intervention.

includes other adverse events, for example, death and MI. Furthermore, prasugrel and ticagrelor are gradually replacing the use of clopidogrel due to better clinical outcomes. This may also influence the outcomes in detecting differences in ST. In addition to the stent types, other factors such as lesion characteristics including: long lesions, bifurcation lesions, and acute coronary syndrome vs stable coronary disease all have a major influence on the ischemic event rates. Patients who have preexisting bleeding-prone conditions such as gastritis or gastrointestinal ulcer disease have a higher risk for bleeding and are likely to develop major bleeding with prolonged DAPT. It is difficult to extrapolate the conclusions of these studies to our current practice using the state-of-the-art second-generation DES with improved antiplatelet agents.

\section{Current postulated duration of DAPT - individualized therapy}

Therefore, before more clinical trials are conducted using a larger population, more unified stent types, and lesion characteristics, it may be postulated that second-generation DES may be safe for a shorter duration of DAPT if there is a clinical indication to shorten the duration of treatment, such as increased risk of gastrointestinal bleeding or need for surgical intervention. Longer duration of DAPT with secondgeneration DES may be used if lesion types and characteristics are highly complex and the patient is at a higher risk, such as acute coronary syndrome with multi-vessel disease. Therefore, an individualized, case-by-case approach in regard to the use of second-generation DES and DAPT, in the setting of a 
judicious and comprehensive consideration of the bleeding and thrombotic risks of each patient, should be exercised.

\section{Bioresorbable polymer stents, polymer-free stents, and fully bioresorbable scaffolds with vascular restoration}

The coronary stents currently available in the US are permanent implants composed of a metallic alloy scaffold, and all have a durable polymer, which remains permanently on the stent after the drug is eluted. While DES have improved outcomes for patients compared to BMS, they have several limitations. The development of ST and residual rates of ISR after DES are the main reasons for the development of newer coronary artery stents in the hope of further improving outcomes.

The durable polymer, which coats the metallic scaffold, itself may result in vascular inflammation or delayed endothelialization and healing therefore, contributing to the risk of ST. ${ }^{114}$ Henceforth, two very large network meta-analyses reflect the current evidence regarding bioresorbable polymer stents. They included all coronary stents, including BMS, first- and second-generation DES, and bioresorbable polymer stents and demonstrated that the rates of TLR were comparable between bioresorbable polymer DES and the standard EES. ${ }^{115}$ Bioresorbable polymer stents were inferior to EES with regard to definite ST and were associated with increased mortality. ${ }^{115}$ In addition, compared with EES, bioresorbable polymer biolimus-eluting stents were associated with an increased risk of MI. ${ }^{116}$ In conclusion, the bioresorbable polymer stents have not shown excellent clinical outcomes in comparison to the state-of-the-art second-generation durable polymer DES.

A polymer-free stent, similar to a bioresorbable polymer stent, may be associated with less chronic inflammation and improved vascular healing, therefore, improved clinical outcomes. The challenge in designing a polymer-free stent is the difficulty in achieving adequate levels of the anti-proliferative drug over time to effectively inhibit neointimal proliferation and hence, ISR. In addition, the polymer-free stents have a BMS scaffold which is filled with the anti-proliferative drug. This technology uses laser cut, microscopic holes in the metal scaffold to allow for drug storage and elution. Clinical experience with polymer-free stents is still in the early stages and limited, and all polymer-free stents are currently purely investigational. In the ISAR-TEST trial, 450 patients with de novo native coronary artery lesions, excluding left main coronary artery disease, were randomly assigned to a rapamycin-coated Yukon DES (rapamycin stent) or the polymer-based, paclitaxel-eluting Taxus stent (paclitaxel stent). There were no significant differences between the groups in terms of late lumen loss, angiographic restenosis, or TLR due to restenosis. ${ }^{117}$ In another ISAR trial, ${ }^{118}$ which was a prospective, observational, systematic angiographic follow-up study conducted at two German centers, 2,588 patients underwent stenting with either a durable polymer rapamycin-eluting stent (RES), polymer-free RES, or a permanent-polymer PES, and the primary endpoint of late lumen loss at 2 years followup was significantly less for the polymer-free RES vs the other two groups. In conclusion, further studies are needed to establish excellent clinical outcomes of the polymer-free stents in comparison to the state-of-the-art durable polymer second-generation DES in current use today.

Fully bioresorbable scaffold devices, also known as BRS, have been designed in an attempt to overcome some of the disadvantages of DES. In these devices, the scaffold is in place only long enough to protect against subacute closure, wall recoil, and ISR. These stents have the potential to reduce the problems of very-late ST and the requirement for prolonged DAPT. In addition to reducing long-term adverse events associated with metallic stent struts, including stent fracture, vascular endothelial dysfunction, and neoatherosclerosis, BRS have the advantages of restoring vascular functions, ie, endothelial function and SMC phenotype, shielding and recapping of the plaque, late lumen enlargement, and remodeling function. Currently, there are four major categories of materials used for BRS. These are poly-L-lactic acid (PLLA) and co-polymers, tyrosine polycarbonate, magnesium alloys, and nitride iron (Table 5). There are at least two types of BRS approved in Europe and another 20 types of BRS in current clinical trials or under development.

The first-in-human fully BRS, the Igaki-Tamai stent, was constructed of a thick, PLLA polymer scaffold and this initial bioresorbable stent was not drug-eluting. In a long-term safety report of the 10-year outcomes of the first 50 patients treated with 84 stents, survival rates free of allcause death, cardiac death, and MACE were $87 \%, 98 \%$, and $50 \%$, respectively. ${ }^{119}$ The cumulative rates of TVR were $16 \%$, $18 \%$, and $28 \%$ at 1,5 , and 10 years, respectively. Two cases of definite ST were noted. Most stent struts were noted to have been absorbed by 3 years using IVUS.

The safety and efficacy of the first-generation fully bioresorbable EES (BVS-EES) (Abbott Vascular, Abbott 
Table 5 Bioabsorbable stents and stages of production

\begin{tabular}{|c|c|c|c|}
\hline $\begin{array}{l}\text { Category of } \\
\text { material }\end{array}$ & $\begin{array}{l}\text { Example of } \\
\text { manufacturer }\end{array}$ & Stent name & $\begin{array}{l}\text { Status of } \\
\text { approval }\end{array}$ \\
\hline $\begin{array}{l}\text { PLLA and } \\
\text { co-polymers }\end{array}$ & Abbott Vascular & Absorb & CE mark \\
\hline Magnesium alloys & Biotronik & DREAMS & In clinical trial \\
\hline $\begin{array}{l}\text { Tyrosine } \\
\text { polycarbonate }\end{array}$ & Reva & Fantom & $\begin{array}{l}\text { Under } \\
\text { preclinical study }\end{array}$ \\
\hline Nitride iron & Lifetech & $\begin{array}{l}\text { Lifetech Nitride } \\
\text { Iron Stent }\end{array}$ & $\begin{array}{l}\text { Under } \\
\text { preclinical study }\end{array}$ \\
\hline
\end{tabular}

Abbreviation: PLLA, poly-L-lactic acid.

Laboratories, Abbott Park, IL, USA) were evaluated in the open-label, prospective ABSORB study, which enrolled 30 selected patients with single de novo coronary lesions. ${ }^{120,121}$ This stent was also made of a backbone of PLLA with a coating of poly-D-L-lactic acid that contained and released the anti-proliferative agent. Although the 2-year results demonstrated its safety and efficacy with a sustained low MACE rate and no cases of ST up to 4 years, ${ }^{122}$ subsequent reports suggested less than optimal radial integrity and demonstrated shrinkage of the device at 6 months, which caused significant late lumen loss. ${ }^{123}$ Therefore, the stent design and manufacturing protocol of the polymer were modified to provide better vascular support and a slower release of everolimus. The BVS-EES scaffold received a CE mark approval in 2011 and has been in clinical use in Europe and parts of Asia.

The newer second-generation BVS-EES design with intended improved radial strength has been evaluated in the ABSORB BVS 1.1 study in which 101 patients received a single stent. Follow-up for clinical and imaging outcomes at different time intervals was intended for two separate cohorts: 45 patients (cohort 1), and 56 patients (cohort 2). ${ }^{123,124}$ At 2 years follow-up, the newer BVS-EES revised scaffold had enhanced radial strength with sustained outcomes, without any ST; however, stent struts were still present. ${ }^{125}$

In the largest trial of the fully bioresorbable BVS-EES scaffold to date, the ABSORB-II trial, 501 patients with evidence of myocardial ischemia and one or two de novo native lesions were randomly assigned in a 2:1 ratio to receive either a BVS-EES or a durable metallic EES. ${ }^{126}$ The co-primary endpoints were vasomotion and lumen diameter at 3 years. The secondary endpoints were composite clinical endpoints, including death, TVR, device and procedural success, and angina status at 6 and 12 months. The interim 1-year follow-up results were published in September 2014 and it was demonstrated that the acute lumen gain is significantly lower for the BVS-EES by coronary angiography and IVUS. ${ }^{127}$ However, the cumulative rates of new-onset or worsening angina were lower in the BVS-EES group, although performance during maximal exercise and angina status was similar. The 1-year composite device-oriented endpoint was similar between the two groups. However, three patients in the BVS-EES group had ST vs none in the metallic EES group. ${ }^{127}$ Although the theoretical advantages of the fully BRS are appealing, the scientific community needs to await the final results of this and the larger ongoing ABSORB III and IV trials to evaluate the specific advantages and disadvantages of this device's technology, in addition to safety profiles in comparison to the state-of-the-art second-generation durable metallic DES.

\section{DES in advancing the treatment of complex/multi-vessel coronary artery disease}

Multiple clinical trials have been performed comparing PCI with CABG surgery starting in the era of POBA, and subsequently in the era of BMS, and then in the eras of first- and second-generation DES.

\section{Robust clinical outcomes comparing POBA or BMS with CABG in treating complex/multi-vessel coronary disease}

There have been seven randomized published trials comparing POBA vs CABG in treating symptomatic patients with multi-vessel disease. ${ }^{128-134}$ All of these seven trials demonstrated no significant mortality difference between the POBA and CABG treatment groups. Among these trials, only the BARI trial ${ }^{134}$ reported the 10 -year survival for the complete cohort with $71.0 \%$ for POBA and $73.5 \%$ for CABG $(P=0.18)$. At 10 years, the POBA group had significantly higher subsequent revascularization rates than the CABG group $(76.8 \%$ vs $20.3 \%, P<0.001)$; however, angina rates for the two groups were similar. ${ }^{134}$ In regard to comparing BMS with $\mathrm{CABG}$ in treating multi-vessel disease, there were four clinical trials completed: ARTS-I, ${ }^{135}$ ERACI-II, ${ }^{136}$ SOS,${ }^{137}$ and AWESOME. ${ }^{138}$ Again, these clinical trials demonstrated no difference in the mortality rates except for higher rates of revascularization within the PCI cohorts. Furthermore, there was a total of four important clinical trials comparing the first-generation DES and CABG including: ARTS-II, ${ }^{139}$ ERACI-III, ${ }^{140}$ SYNTAX,,${ }^{141}$ and recently FREEDOM. ${ }^{142}$ 
The performance of first-generation DES compared with CABG in the treatment of CAD in non-randomized studies

The ARTS II study ${ }^{139}$ was a non-randomized trial with the Cypher SES, which applied the same inclusion and exclusion criteria, endpoints, and protocol definitions as the ARTS-I study, ${ }^{135}$ and its aim was to determine the safety and efficacy of the Cypher stent in patients with multi-vessel disease, in addition to comparing the outcomes to the historical outcomes of the ARTS-I trial. At 5 years follow-up of the ARTS-II trial, ${ }^{143}$ the death/stroke/MI event-free survival rate was $87.1 \%$ in ARTS-II SES vs $86.0 \%(P=0.1)$ and $81.9 \%(P=0.007)$ in ARTS-I CABG and BMS cohorts, respectively. Thus, the ARTS-II trial demonstrated that the SES had a safety record comparable to $\mathrm{CABG}$ and superior to BMS. Patients with multi-vessel CAD who met the ERACI-II trial ${ }^{136}$ clinical and angiographic inclusion criteria were treated with DES and enrolled in the ERACI-III registry. ${ }^{140}$ The primary endpoint of 3 years MACE was lower in ERACI-III DES (22.7\%) than in ERACI-II BMS $(29.8 \%, P=0.015)$, mainly reflecting less TVR (14.2 vs $24.4 \%, P=0.009$ ) in the DES vs BMS groups, respectively. MACE rates at 3 years were the same in DES and CABG-treated patients $(22.7$ vs $22.7 \%$, risk ratio [RR] $=1$, $95 \%$ confidence interval $=0.710-1.406)$. Thus, the ERACI-III registry demonstrated superior efficacy of the DES compared to BMS and similar outcomes with DES and CABG.

\section{The failure of first generation DES compared with CABG in treating multi- vessel $C A D$ in randomized studies}

The SYNTAX trial is a landmark randomized study which compared CABG with first-generation DES for the treatment of patients with left main coronary disease and/or three-vessel disease with approximately 900 patients in either group. ${ }^{141}$ At 5 years follow-up, estimates of MI (3.8\% in the CABG group vs $9.7 \%$ in the PCI group, $P<0.0001)$ and repeat revascularization $(13.7 \%$ vs $25.9 \%, P<0.0001)$ were significantly increased with PCI compared to CABG. All-cause mortality (11.4\% in the CABG group vs $13.9 \%$ in the PCI group, $P=0.10$ ) and stroke (3.7\% vs $2.4 \%, P=0.09$ ) were not significantly different between the two groups. ${ }^{144}$ Patients with a low SYNTAX score $(\leq 22)$ had a similar rate of MACE in the PCI group compared to the CABG group. However, patients with intermediate (23-32) or high ( $\geq 33$ ) SYNTAX scores had an increased rate of MACE in the PCI group compared to the CABG group. Based on the use of first-generation DES in PCI vs CABG, the SYNTAX trial concluded that $\mathrm{CABG}$ should be the standard of care in treating multi-vessel/left main disease with intermediate or high SYNTAX scores. ${ }^{144}$ The FREEDOM trial ${ }^{142}$ is another major landmark randomized trial assigning patients with diabetes and multi-vessel coronary artery disease to undergo either PCI with first-generation DES (using PES or SES) vs CABG with approximately 950 patients in either group. At 5 years follow-up, the primary composite endpoint of death/infarction/ stroke rate was $26.6 \%$ in first-generation DES group and $18.7 \%$ in CABG group ( $P=0.005)$. The study concluded that for patients with diabetes and advanced coronary artery disease, $C A B G$ was superior to PCI in that it significantly reduced rates of all-cause mortality and MI but with a higher rate of stroke. ${ }^{142}$

\section{The dilemma of comparing DES with CABG \\ DES treatment as an evolving device-based modality, compared to a solid but static treatment - CABG}

As mentioned earlier, various stent comparison trials and meta-analyses have demonstrated that second-generation DES have much less ST and less need for revascularization. Current trials, including SYNTAX, FREEDOM, and ARTSII only used first-generation DES. The ST was reported at up to $6 \%$ to $10 \%$ at the end of 5 years follow-up for these three landmark studies. ST is associated with a very high mortality rate which obviously contributed to the worse outcomes in the group of patients treated with first-generation DES compared with $\mathrm{CABG}$ in these landmark trials. In a recent meta-analysis comparing DES vs CABG in treating diabetic patients with multi-vessel disease, ${ }^{145}$ it was demonstrated that the revascularization rates with PCI have steadily decreased from POBA to first-generation DES, and then to second-generation DES. The need for revascularization in the patients treated with second-generation DES was not significantly higher than patients treated with $\mathrm{CABG}$. Along these lines, there are two randomized, currently ongoing clinical trials, ${ }^{146}$ that is, EXCEL and NOBLE using newer generation DES vs CABG in treating patients with unprotected left-main disease and complex coronary disease with low-to-intermediate SYNTAX scores, both of which should further elucidate a more contemporary comparison of PCI with newer generation DES vs CABG surgery. The initial reports may be available in 2016 .

\section{Completeness of revascularization}

Patients with multi-vessel CAD are often treated with incomplete revascularization in either the PCI or CABG group. However, the rates of incomplete revascularization are 
usually higher in the stent group, most likely due to chronic total occlusions or severe tortuous or calcified untreatable lesions. In the SYNTAX trial, incomplete revascularization rates were $43.3 \%$ vs $36.8 \%$ in the PCI vs CABG groups, respectively; in ARTS-II the rates were $39 \%$ vs $16 \%$, respectively. A recent meta-analysis demonstrated that the completeness of revascularization in treatment of multi-vessel disease is associated with a $30 \%$ lower long-term mortality rate relative to incomplete revascularization regardless of treatment strategies utilized, that is, PCI or CABG. ${ }^{147}$ Furthermore, in the PCI group, complete revascularization was associated with a $22 \%$ reduction in $\mathrm{MI}$ and a $26 \%$ reduction in repeat revascularization. ${ }^{147}$ Furthermore, the ongoing improvement in treating chronic total occlusions and highly complex lesions such as tortuous and/or calcified lesions may further decrease the gap in the difference in outcomes between PCI with second-generation DES vs CABG.

\section{Inclusion of clinically non-significant lesions as a part of multi-vessel disease}

Less than clinically significant stenoses in patients with multi-vessel disease could potentially have been included as an index lesion in multiple clinical trials. Treatment of less than clinically significant lesions may inadvertently increase the risk of the procedure and worsen the prognosis such as restenosis or ST. Therefore, the current utilization of fractional flow reserve in a physiologic assessment of disease will likely optimize the strategy of PCI and, therefore, treatment of only the hemodynamically significant lesions may translate into improved outcomes.

\section{Conclusion}

The first-generation DES delivered major advances in the percutaneous treatment of obstructive CAD over their predecessor BMS in regards to significant improvements in ISR. The second-generation DES have been established as safe and efficacious in addition to providing improvements in outcomes compared to their first-generation predecessors. The significant differences in outcomes were emphasized in multiple randomized trials, large meta-analyses, and registry data, as previously described. Therefore, the second-generation DES represent the state-of-the-art and the current standard in PCI care of obstructive coronary disease, and the three currently available second-generation DES have been demonstrated to have similar efficacy and safety outcomes. Furthermore, the dilemma of optimal duration of DAPT continues to be a passionate topic for discussion in the interventional realm and given the current available data, we currently propose a fine balance of reducing thrombotic risk and reducing the risk of bleeding on a patient-specific level of management. In regard to the theoretical advantages of the BRS, which may be appealing, we need to await the results of large ongoing trials to evaluate their specific advantages and disadvantages, in addition to safety profiles in comparison to the state-of-the-art second-generation durable metallic EES. In regard to the quickly changing realm of percutaneous vs surgical revascularization, CABG remains the standard of care for patients with advanced coronary disease and diabetes, and for patients with complex three-vessel/left-main disease with intermediate-to-high SYNTAX scores. However, this paradigm may be slowly changing with the advent and further improvement of the second-generation DES devices in addition to the overall improvement of the various aspects in the percutaneous management of coronary disease.

\section{Disclosure}

The authors have no conflict of interest to disclose.

\section{References}

1. Gruntzig AR, Senning A, Siegenthaler WE. Nonoperative dilatation of coronary-artery stenosis: percutaneous transluminal coronary angioplasty. $N$ Engl J Med. 1979;301(2):61-68.

2. Cannan CR, Yeh W, Kelsey SF, Cohen HA, Detre K, Williams DO, Incidence and predictors of target vessel revascularization following percutaneous transluminal coronary angioplasty: a report from the National Heart, Lung, and Blood Institute Percutaneous Transluminal Coronary Angioplasty Registry. Am J Cardiol. 1999;84(2):170-175.

3. Ormiston JA, Stewart FM, Roche AH, Webber BJ, Whitlock RM, Webster MW. Late regression of the dilated site after coronary angioplasty: a 5-year quantitative angiographic study. Circulation. 1997;96(2):468-474.

4. Guiteras-Val P, Varas-Lorenzo C, Garcia-Picart J, Marti-Claramunt V, Auge-Sanpera JM. Clinical and sequential angiographic follow-up six months and 10 years after successful percutaneous transluminal coronary angioplasty. Am J Cardiol. 1999;83(6):868-874.

5. Liu MW, Parks JM, Cox DA, et al. Vascular Biology of Mechanical Intervention. In: Stack RS, Roubin GS, O'Neill WW, editors. Interventional Cardiovascular Medicine, Principles and Practice. 2nd ed. Philadelphia: Churchill Livingstone; 2001.

6. Muhlestein JB, Zidar JP, Blazing MA. The Vascular Biology of Restenosis: An Overview. In: Stack RS, Roubin GS, O'Neill WW, editors. Interventional Cardiovascular Medicine, Principles and Practice. 2nd ed. Philadelphia: Churchill Livingstone; 2001.

7. Mintz GS, Popma JJ, Pichard AD, et al. Arterial remodeling after coronary angioplasty: a serial intravascular ultrasound study. Circulation. 1996; 94(1):35-43.

8. Hoffmann R, Mintz GS, Dussaillant GR, et al. Patterns and mechanisms of in-stent restenosis. A serial intravascular ultrasound study. Circulation. 1996;94(6):1247-1254.

9. Virmani R, Farb A. Pathology of in-stent restenosis. Curr Opin Lipidol. 1999;10(6):499-506.

10. Fischman DL, Leon MB, Baim DS, et al. A randomized comparison of coronary-stent placement and balloon angioplasty in the treatment of coronary artery disease. Stent Restenosis Study Investigators. $N$ Engl J Med. 1994;331(8):496-501.

11. Serruys PW, de Jaegere P, Kiemeneij F, et al. A comparison of balloonexpandable-stent implantation with balloon angioplasty in patients with coronary artery disease. Benestent Study Group. N Engl J Med. 1994; 331(8):489-495. 
12. Cutlip DE, Chauhan MS, Baim DS, et al. Clinical restenosis after coronary stenting: perspectives from multicenter clinical trials. $\mathrm{J} \mathrm{Am}$ Coll Cardiol. 2002;40(12):2082-2089.

13. O'Brien ER, Ma X, Simard T, Pourdjabbar A, Hibbert B. Pathogenesis of neointima formation following vascular injury. Cardiovasc Hematol Disord Drug Targets. 2011;11(1):30-39.

14. Liu MW, Roubin GS, King SB 3rd. Restenosis after coronary angioplasty. Potential biologic determinants and role of intimal hyperplasia. Circulation. 1989;79(6):1374-1387.

15. Schwartz RS, Henry TD. Pathophysiology of coronary artery restenosis. Rev Cardiovasc Med. 2003;3 Suppl 5:S4-S9.

16. Ross R, Glomset JA. The pathogenesis of atherosclerosis (second of two parts). N Engl J Med. 1976;295(8):420-425.

17. Ross R, Glomset JA. The pathogenesis of atherosclerosis (first of two parts). N Engl J Med. 1976;295(7):369-377.

18. Glover C, Ma X, Chen YX, et al. Human in-stent restenosis tissue obtained by means of coronary atherectomy consists of an abundant proteoglycan matrix with a paucity of cell proliferation. Am Heart J. 2002;144(4):702-709.

19. Anderson PG, Bajaj RK, Baxley WA, Roubin GS. Vascular pathology of balloon-expandable flexible coil stents in humans. J Am Coll Cardiol. 1992;19(2):372-381.

20. Komatsu R, Ueda M, Naruko T, Kojima A, Becker AE. Neointimal tissue response at sites of coronary stenting in humans: macroscopic, histological, and immunohistochemical analyses. Circulation. 1998;98(3): 224-233.

21. van Beusekom HM, Whelan DM, Hofma SH, et al. Long-term endothelial dysfunction is more pronounced after stenting than after balloon angioplasty in porcine coronary arteries. J Am Coll Cardiol. 1998;32(4): 1109-1117.

22. Karas SP, Gravanis MB, Santoian EC, Robinson KA, Anderberg KA, King SB 3rd. Coronary intimal proliferation after balloon injury and stenting in swine: an animal model of restenosis. J Am Coll Cardiol. 1992;20(2):467-474.

23. Morton AC, Arnold ND, Crossman DC, Gunn J. Response of very small ( $2 \mathrm{~mm})$ porcine coronary arteries to balloon angioplasty and stent implantation. Heart. 2004;90(3):324-327.

24. Gunn J, Arnold N, Chan KH, Shepherd L, Cumberland DC, Crossman DC. Coronary artery stretch versus deep injury in the development of in-stent neointima. Heart. 2002;88(4):401-405.

25. Schwartz RS, Huber KC, Murphy JG, et al. Restenosis and the proportional neointimal response to coronary artery injury: results in a porcine model. J Am Coll Cardiol. 1992;19(2):267-274.

26. Farb A, Weber DK, Kolodgie FD, Burke AP, Virmani R. Morphological predictors of restenosis after coronary stenting in humans. Circulation. 2002;105(25):2974-2980.

27. Hwang CW, Wu D, Edelman ER. Physiological transport forces govern drug distribution for stent-based delivery. Circulation. 2001;104(5): 600-605.

28. Takebayashi H, Mintz GS, Carlier SG, et al. Nonuniform strut distribution correlates with more neointimal hyperplasia after sirolimus-eluting stent implantation. Circulation. 2004;110(22):3430-3434.

29. Garg S, Serruys PW. Coronary stents: current status. J Am Coll Cardiol. 2010;56(10 Suppl):S1-S42.

30. Sousa JE, Serruys PW, Costa MA. New frontiers in cardiology: drugeluting stents: Part II. Circulation. 2003;107(18):2383-2389.

31. Sousa JE, Serruys PW, Costa MA. New frontiers in cardiology: drugeluting stents: Part I. Circulation. 2003;107(17):2274-2279.

32. Marx SO, Jayaraman T, Go LO, Marks AR. Rapamycin-FKBP inhibits cell cycle regulators of proliferation in vascular smooth muscle cells. Circ Res. 1995;76(3):412-417.

33. Flechner SM, Gurkan A, Hartmann A, et al. A randomized, open-label study of sirolimus versus cyclosporine in primary de novo renal allograft recipients. Transplantation. 2013;95(10):1233-1241.

34. Marx SO, Marks AR. Bench to bedside: the development of rapamycin and its application to stent restenosis. Circulation. 2001;104(8): 852-855.
35. Poon M, Marx SO, Gallo R, Badimon JJ, Taubman MB, Marks AR. Rapamycin inhibits vascular smooth muscle cell migration. J Clin Invest. 1996;98(10):2277-2283

36. Sousa JE, Sousa AG, Costa MA, Abizaid AC, Feres F. Use of rapamycinimpregnated stents in coronary arteries. Transplant Proc. 2003; 35(3 Suppl):165S-170S.

37. Sousa JE, Costa MA, Abizaid AC, et al. Sustained suppression of neointimal proliferation by sirolimus-eluting stents: one-year angiographic and intravascular ultrasound follow-up. Circulation. 2001; 104(17):2007-2011.

38. Morice MC, Serruys PW, Sousa JE, et al. A randomized comparison of a sirolimus-eluting stent with a standard stent for coronary revascularization. $N$ Engl J Med. 2002;346(23):1773-1780.

39. Wani MC, Taylor HL, Wall ME, Coggon P, McPhail AT. Plant antitumor agents. VI. The isolation and structure of taxol, a novel antileukemic and antitumor agent from Taxus brevifolia. JAm Chem Soc. 1971;93(9): 2325-2327.

40. Schiff PB, Fant J, Horwitz SB. Promotion of microtubule assembly in vitro by taxol. Nature. 1979;277(5698):665-667.

41. Sollott SJ, Cheng L, Pauly RR, et al. Taxol inhibits neointimal smooth muscle cell accumulation after angioplasty in the rat. J Clin Invest. 1995;95(4):1869-1876.

42. Moses JW, Leon MB, Popma JJ, et al. Sirolimus-eluting stents versus standard stents in patients with stenosis in a native coronary artery. N Engl J Med. 2003;349(14):1315-1323.

43. Stone GW, Ellis SG, Cox DA, et al. A polymer-based, paclitaxel-eluting stent in patients with coronary artery disease. $N$ Engl J Med. 2004; 350(3):221-231.

44. Weisz G, Leon MB, Holmes DR Jr, et al. Five-year follow-up after sirolimus-eluting stent implantation results of the SIRIUS (SirolimusEluting Stent in De-Novo Native Coronary Lesions) Trial. J Am Coll Cardiol. 2009;53(17):1488-1497.

45. Ellis SG, Stone GW, Cox DA, et al. Long-term safety and efficacy with paclitaxel-eluting stents: 5-year final results of the TAXUS IV clinical trial (TAXUS IV-SR: Treatment of De Novo Coronary Disease Using a Single Paclitaxel-Eluting Stent). JACC Cardiovasc Interv. 2009;2(12): 1248-1259.

46. Kimura T, Morimoto T, Nakagawa Y, et al. Very late stent thrombosis and late target lesion revascularization after sirolimus-eluting stent implantation: five-year outcome of the j-Cypher Registry. Circulation. 2012;125(4):584-591.

47. Sarno G, Lagerqvist B, Frobert O, et al. Lower risk of stent thrombosis and restenosis with unrestricted use of 'new-generation' drug-eluting stents: a report from the nationwide Swedish Coronary Angiography and Angioplasty Registry (SCAAR). Eur Heart J. 2012;33(5):606-613.

48. Schampaert E, Cohen EA, Schluter M, et al. The Canadian study of the sirolimus-eluting stent in the treatment of patients with long de novo lesions in small native coronary arteries (C-SIRIUS). J Am Coll Cardiol. 2004;43(6):1110-1115.

49. Schofer J, Schluter M, Gershlick AH, et al. Sirolimus-eluting stents for treatment of patients with long atherosclerotic lesions in small coronary arteries: double-blind, randomised controlled trial (E-SIRIUS). Lancet. 2003;362(9390):1093-1099.

50. Moussa I, Leon MB, Baim DS, et al. Impact of sirolimus-eluting stents on outcome in diabetic patients: a SIRIUS (SIRolImUS-coated Bx Velocity balloon-expandable stent in the treatment of patients with de novo coronary artery lesions) substudy. Circulation. 2004;109(19):2273-2278.

51. Spaulding C, Henry P, Teiger E, et al. Sirolimus-eluting versus uncoated stents in acute myocardial infarction. N Engl J Med. 2006;355(11): 1093-1104.

52. Grube E, Silber S, Hauptmann KE, et al. TAXUS I: six- and twelvemonth results from a randomized, double-blind trial on a slow-release paclitaxel-eluting stent for de novo coronary lesions. Circulation. 2003; 107(1):38-42.

53. Colombo A, Drzewiecki J, Banning A, et al. Randomized study to assess the effectiveness of slow- and moderate-release polymer-based paclitaxel-eluting stents for coronary artery lesions. Circulation. 2003; 108(7):788-794. 
54. Stone GW, Ellis SG, Cox DA, et al. One-year clinical results with the slow-release, polymer-based, paclitaxel-eluting TAXUS stent: the TAXUS-IV trial. Circulation. 2004;109(16):1942-1947.

55. Dawkins KD, Grube E, Guagliumi G, et al. Clinical efficacy of polymerbased paclitaxel-eluting stents in the treatment of complex, long coronary artery lesions from a multicenter, randomized trial: support for the use of drug-eluting stents in contemporary clinical practice. Circulation. 2005;112(21):3306-3313.

56. Stone GW, Ellis SG, Cannon L, et al. Comparison of a polymer-based paclitaxel-eluting stent with a bare metal stent in patients with complex coronary artery disease: a randomized controlled trial. JAMA. 2005; 294(10):1215-1223.

57. Windecker S, Remondino A, Eberli FR, et al. Sirolimus-eluting and paclitaxel-eluting stents for coronary revascularization. $N$ Engl J Med. 2005;353(7):653-662.

58. Raber L, Wohlwend L, Wigger M, et al. Five-year clinical and angiographic outcomes of a randomized comparison of sirolimus-eluting and paclitaxel-eluting stents: results of the Sirolimus-Eluting Versus Paclitaxel-Eluting Stents for Coronary Revascularization LATE trial. Circulation. 2011;123(24):2819-2828.

59. Stettler C, Wandel S, Allemann S, et al. Outcomes associated with drugeluting and bare-metal stents: a collaborative network meta-analysis. Lancet. 2007;370(9591):937-948.

60. Ong AT, McFadden EP, Regar E, de Jaegere PP, van Domburg RT, Serruys PW. Late angiographic stent thrombosis (LAST) events with drug-eluting stents. J Am Coll Cardiol. 2005;45(12):2088-2092.

61. Westphal S. Concerns Prompt Some Hospitals To Pare Use of DrugCoated Stents. Wall Street Journal. 2006 Jun 22.

62. Wenaweser P, Daemen J, Zwahlen M, et al. Incidence and correlates of drug-eluting stent thrombosis in routine clinical practice. 4-year results from a large 2-institutional cohort study. J Am Coll Cardiol. 2008; 52(14):1134-1140.

63. Camenzind E, Steg PG, Wijns W. Stent thrombosis late after implantation of first-generation drug-eluting stents: a cause for concern Circulation. 2007;115(11):1440-1455.

64. Eisenstein EL, Anstrom KJ, Kong DF, et al. Clopidogrel use and longterm clinical outcomes after drug-eluting stent implantation. JAMA. 2007;297(2):159-168.

65. Finn AV, Nakazawa G, Joner M, et al. Vascular responses to drug eluting stents: importance of delayed healing. Arterioscler Thromb Vasc Biol. 2007;27(7):1500-1510.

66. Ellis SG, Colombo A, Grube E, et al. Incidence, timing, and correlates of stent thrombosis with the polymeric paclitaxel drug-eluting stent: a TAXUS II, IV, V, and VI meta-analysis of 3,445 patients followed for up to 3 years. J Am Coll Cardiol. 2007;49(10):1043-1051.

67. Kastrati A, Mehilli J, Pache J, et al. Analysis of 14 trials comparing sirolimus-eluting stents with bare-metal stents. $N$ Engl J Med. 2007; 356(10):1030-1039.

68. Kolandaivelu K, Swaminathan R, Gibson WJ, et al. Stent thrombogenicity early in high-risk interventional settings is driven by stent design and deployment and protected by polymer-drug coatings. Circulation. 2011;123(13):1400-1409.

69. Stone GW, Moses JW, Ellis SG, et al. Safety and efficacy of sirolimusand paclitaxel-eluting coronary stents. $N$ Engl J Med. 2007;356(10): 998-1008.

70. Levine GN, Bates ER, Blankenship JC, et al. 2011 ACCF/AHA/SCAI Guideline for Percutaneous Coronary Intervention: a report of the American College of Cardiology Foundation/American Heart Association Task Force on Practice Guidelines and the Society for Cardiovascular Angiography and Interventions. Circulation. 2011;124(23): e574-e651.

71. Grines CL, Bonow RO, Casey DE Jr, et al. Prevention of premature discontinuation of dual antiplatelet therapy in patients with coronary artery stents: a science advisory from the American Heart Association, American College of Cardiology, Society for Cardiovascular Angiography and Interventions, American College of Surgeons, and American Dental Association, with representation from the American College of Physicians. J Am Coll Cardiol. 2007;49(6):734-739.
72. Brar SS, Kim J, Brar SK, et al. Long-term outcomes by clopidogrel duration and stent type in a diabetic population with de novo coronary artery lesions. J Am Coll Cardiol. 2008;51(23):2220-2227.

73. Steinhubl SR, Berger PB, Mann JT 3rd, et al. Early and sustained dual oral antiplatelet therapy following percutaneous coronary intervention: a randomized controlled trial. JAMA. 2002;288(19): 2411-2420.

74. Hibbert B, Ma X, Pourdjabbar A, et al. Inhibition of endothelial progenitor cell glycogen synthase kinase-3beta results in attenuated neointima formation and enhanced re-endothelialization after arterial injury. Cardiovasc Res. 2009;83(1):16-23.

75. Hill JM, Zalos G, Halcox JP, et al. Circulating endothelial progenitor cells, vascular function, and cardiovascular risk. $N$ Engl J Med. 2003;348(7):593-600.

76. Joner M, Finn AV, Farb A, et al. Pathology of drug-eluting stents in humans: delayed healing and late thrombotic risk. J Am Coll Cardiol. 2006;48(1):193-202.

77. Virmani R, Guagliumi G, Farb A, et al. Localized hypersensitivity and late coronary thrombosis secondary to a sirolimus-eluting stent: should we be cautious? Circulation. 2004;109(6):701-705.

78. Huang KN, Grandi SM, Filion KB, Eisenberg MJ. Late and very late stent thrombosis in patients with second-generation drug-eluting stents. Can J Cardiol. 2013;29(11):1488-1494.

79. Joner M, Nakazawa G, Finn AV, et al. Endothelial cell recovery between comparator polymer-based drug-eluting stents. J Am Coll Cardiol. 2008;52(5):333-342.

80. Rittersma SZ, de Winter RJ, Koch KT, et al. Impact of strut thickness on late luminal loss after coronary artery stent placement. Am J Cardiol. 2004;93(4):477-480.

81. Finn AV, Joner M, Nakazawa G, et al. Pathological correlates of late drug-eluting stent thrombosis: strut coverage as a marker of endothelialization. Circulation. 2007;115(18):2435-2441.

82. Kim JS, Jang IK, Kim JS, et al. Optical coherence tomography evaluation of zotarolimus-eluting stents at 9-month follow-up: comparison with sirolimus-eluting stents. Heart. 2009;95(23): 1907-1912.

83. Cole OJ, Shehata M, Rigg KM. Effect of SDZ RAD on transplant arteriosclerosis in the rat aortic model. Transplant Proc. 1998;30(5): 2200-2203.

84. Chin-Quee SL, Hsu SH, Nguyen-Ehrenreich KL, et al. Endothelial cell recovery, acute thrombogenicity, and monocyte adhesion and activation on fluorinated copolymer and phosphorylcholine polymer stent coatings. Biomaterials. 2010;31(4):648-657.

85. Meredith IT, Worthley S, Whitbourn R, et al. Clinical and angiographic results with the next-generation resolute stent system: a prospective, multicenter, first-in-human trial. JACC Cardiovasc Interv. 2009;2(10): 977-985.

86. Stone GW, Midei M, Newman W, et al. Comparison of an everolimus-eluting stent and a paclitaxel-eluting stent in patients with coronary artery disease: a randomized trial. JAMA. 2008;299(16): 1903-1913.

87. Stone GW, Midei M, Newman W, et al. Randomized comparison of everolimus-eluting and paclitaxel-eluting stents: two-year clinical follow-up from the Clinical Evaluation of the Xience V Everolimus Eluting Coronary Stent System in the Treatment of Patients with de novo Native Coronary Artery Lesions (SPIRIT) III trial. Circulation. 2009;119(5):680-686.

88. Stone GW, Rizvi A, Newman W, et al. Everolimus-eluting versus paclitaxel-eluting stents in coronary artery disease. $N$ Engl J Med. 2010;362(18):1663-1674.

89. Stone GW, Rizvi A, Sudhir K, et al. Randomized comparison of everolimus- and paclitaxel-eluting stents. 2-year follow-up from the SPIRIT (Clinical Evaluation of the XIENCE V Everolimus Eluting Coronary Stent System) IV trial. J Am Coll Cardiol. 2011;58(1):19-25.

90. Kedhi E, Joesoef KS, McFadden E, et al. Second-generation everolimuseluting and paclitaxel-eluting stents in real-life practice (COMPARE): a randomised trial. Lancet. 2010;375(9710):201-209. 
91. Smits PC, Kedhi E, Royaards KJ, et al. 2-year follow-up of a randomized controlled trial of everolimus- and paclitaxel-eluting stents for coronary revascularization in daily practice. COMPARE (Comparison of the everolimus eluting XIENCE-V stent with the paclitaxel eluting TAXUS LIBERTE stent in all-comers: a randomized open label trial). J Am Coll Cardiol. 2011;58(1):11-18.

92. Serruys PW, Silber S, Garg S, et al. Comparison of zotarolimus-eluting and everolimus-eluting coronary stents. $N$ Engl J Med. 2010;363(2): 136-146.

93. Silber S, Windecker S, Vranckx P, Serruys PW; RESOLUTE All Comers investigators. Unrestricted randomised use of two new generation drug-eluting coronary stents: 2-year patient-related versus stent-related outcomes from the RESOLUTE All Comers trial. Lancet. 2011;377(9773):1241-1247.

94. Taniwaki M, Stefanini GG, Silber S, et al. 4-year clinical outcomes and predictors of repeat revascularization in patients treated with new-generation drug-eluting stents: a report from the RESOLUTE All-Comers trial (A Randomized Comparison of a ZotarolimusEluting Stent With an Everolimus-Eluting Stent for Percutaneous Coronary Intervention). J Am Coll Cardiol. 2014;63(16): 1617-1625.

95. von Birgelen C, Sen H, Lam MK, et al. Third-generation zotarolimuseluting and everolimus-eluting stents in all-comer patients requiring a percutaneous coronary intervention (DUTCH PEERS): a randomised, single-blind, multicentre, non-inferiority trial. Lancet. 2014;383(9915):413-423.

96. Stone GW, Teirstein PS, Meredith IT, et al. A prospective, randomized evaluation of a novel everolimus-eluting coronary stent: the PLATINUM (a Prospective, Randomized, Multicenter Trial to Assess an Everolimus-Eluting Coronary Stent System [PROMUS Element] for the Treatment of Up to Two de Novo Coronary Artery Lesions) trial. J Am Coll Cardiol. 2011;57(16): 1700-1708.

97. Stone GW, Teirstein P, Meredith IT, et al. Final Five-Year Results of the Platinum Randomized Trial Comparing Platinum Chromium Promus Element and Cobalt Chromium Xience V Everolimus-Eluting Stents in Workhorse Lesions. J Am Coll Cardiol. 2015;65(10_S).

98. Bangalore S, Kumar S, Fusaro M, et al. Short- and long-term outcomes with drug-eluting and bare-metal coronary stents: a mixed-treatment comparison analysis of 117762 patient-years of follow-up from randomized trials. Circulation. 2012;125(23):2873-2891.

99. Palmerini T, Biondi-Zoccai G, Della Riva D, et al. Stent thrombosis with drug-eluting and bare-metal stents: evidence from a comprehensive network meta-analysis. Lancet. 2012;379(9824):1393-1402.

100. Palmerini T, Benedetto U, Biondi-Zoccai G, et al. Long-Term Safety of Drug-Eluting and Bare-Metal Stents: Evidence From a Comprehensive Network Meta-Analysis. J Am Coll Cardiol. 2015;65(23): 2496-2507.

101. Task Force Members, Montalescot G, Sechtem U, et al. 2013 ESC guidelines on the management of stable coronary artery disease: the Task Force on the management of stable coronary artery disease of the European Society of Cardiology. Eur Heart J. 2013;34(38): 2949-3003.

102. Authors/Task Force members, Windecker S, Kolh P, et al. 2014 ESC/ EACTS Guidelines on myocardial revascularization: The Task Force on Myocardial Revascularization of the European Society of Cardiology (ESC) and the European Association for Cardio-Thoracic Surgery (EACTS)Developed with the special contribution of the European Association of Percutaneous Cardiovascular Interventions (EAPCI). Eur Heart J. 2014;35(37):2541-2619.

103. Mauri L, Kereiakes DJ, Yeh RW, et al. Twelve or 30 months of dual antiplatelet therapy after drug-eluting stents. $N$ Engl J Med. 2014; 371(23):2155-2166.

104. Schulz-Schupke S, Byrne RA, Ten Berg JM, et al. ISAR-SAFE: a randomized, double-blind, placebo-controlled trial of 6 vs 12 months of clopidogrel therapy after drug-eluting stenting. Eur Heart J. 2015;36(20):1252-1263.
105. Gwon HC, Hahn JY, Park KW, et al. Six-month versus 12-month dual antiplatelet therapy after implantation of drug-eluting stents: the Efficacy of Xience/Promus Versus Cypher to Reduce Late Loss After Stenting (EXCELLENT) randomized, multicenter study. Circulation. 2012;125(3):505-513.

106. Feres F, Costa RA, Abizaid A, et al. Three vs twelve months of dual antiplatelet therapy after zotarolimus-eluting stents: the OPTIMIZE randomized trial. JAMA. 2013;310(23):2510-2522.

107. Kim BK, Hong MK, Shin DH, et al. A new strategy for discontinuation of dual antiplatelet therapy: the RESET Trial (REal Safety and Efficacy of 3-month dual antiplatelet Therapy following Endeavor zotarolimus-eluting stent implantation). J Am Coll Cardiol. 2012; 60(15):1340-1348.

108. Colombo A, Chieffo A, Frasheri A, et al. Second-generation drugeluting stent implantation followed by 6-versus 12 -month dual antiplatelet therapy: the SECURITY randomized clinical trial. J Am Coll Cardiol. 2014;64(20):2086-2097.

109. Gilard M, Barragan P, Noryani AA, et al. 6- versus 24-month dual antiplatelet therapy after implantation of drug-eluting stents in patients nonresistant to aspirin: the randomized, multicenter ITALIC trial. J Am Coll Cardiol. 2015;65(8):777-786.

110. Valgimigli M, Campo G, Monti M, et al. Short- versus long-term duration of dual-antiplatelet therapy after coronary stenting: a randomized multicenter trial. Circulation. 2012;125(16):2015-2026.

111. Collet JP, Silvain J, Barthelemy O, et al. Dual-antiplatelet treatment beyond 1 year after drug-eluting stent implantation (ARCTIC-Interruption): a randomised trial. Lancet. 2014;384(9954):1577-1585.

112. Lee CW, Ahn JM, Park DW, et al. Optimal duration of dual antiplatelet therapy after drug-eluting stent implantation: a randomized, controlled trial. Circulation. 2014;129(3):304-312.

113. Giustino G, Baber U, Sartori S, et al. Duration of dual antiplatelet therapy after drug-eluting stent implantation: a systematic review and meta-analysis of randomized controlled trials. J Am Coll Cardiol. 2015;65(13):1298-1310.

114. Garg S, Serruys PW. Coronary stents: looking forward. J Am Coll Cardiol. 2010;56(10 Suppl):S43-S78.

115. Bangalore S, Toklu B, Amoroso N, et al. Bare metal stents, durable polymer drug eluting stents, and biodegradable polymer drug eluting stents for coronary artery disease: mixed treatment comparison metaanalysis. BMJ. 2013;347f6625.

116. Navarese EP, Tandjung K, Claessen B, et al. Safety and efficacy outcomes of first and second generation durable polymer drug eluting stents and biodegradable polymer biolimus eluting stents in clinical practice: comprehensive network meta-analysis. $B M J$. 2013;347f6530.

117. Mehilli J, Kastrati A, Wessely R, et al. Randomized trial of a nonpolymer-based rapamycin-eluting stent versus a polymer-based paclitaxel-eluting stent for the reduction of late lumen loss. Circulation. 2006;113(2):273-279.

118. Byrne RA, Iijima R, Mehilli J, et al. Durability of antirestenotic efficacy in drug-eluting stents with and without permanent polymer. JACC Cardiovasc Interv. 2009;2(4):291-299.

119. Nishio S, Kosuga K, Igaki K, et al. Long-Term ( $>10$ Years) clinical outcomes of first-in-human biodegradable poly-1-lactic acid coronary stents: Igaki-Tamai stents. Circulation. 2012;125(19):2343-2353.

120. Ormiston JA, Serruys PW, Regar E, et al. A bioabsorbable everolimuseluting coronary stent system for patients with single de-novo coronary artery lesions (ABSORB): a prospective open-label trial. Lancet. 2008;371(9616):899-907.

121. Serruys PW, Ormiston JA, Onuma Y, et al. A bioabsorbable everolimuseluting coronary stent system (ABSORB): 2-year outcomes and results from multiple imaging methods. Lancet. 2009;373(9667):897-910.

122. Dudek D, Onuma Y, Ormiston JA, Thuesen L, Miquel-Hebert K, Serruys PW. Four-year clinical follow-up of the ABSORB everolimuseluting bioresorbable vascular scaffold in patients with de novo coronary artery disease: the ABSORB trial. EuroIntervention. 2012;7(9): 1060-1061. 
123. Serruys PW, Onuma Y, Ormiston JA, et al. Evaluation of the second generation of a bioresorbable everolimus drug-eluting vascular scaffold for treatment of de novo coronary artery stenosis: six-month clinical and imaging outcomes. Circulation. 2010;122(22):2301-2312.

124. Serruys PW, Onuma Y, Dudek D, et al. Evaluation of the second generation of a bioresorbable everolimus-eluting vascular scaffold for the treatment of de novo coronary artery stenosis: 12-month clinical and imaging outcomes. J Am Coll Cardiol. 2011;58(15):1578-1588.

125. Ormiston JA, Serruys PW, Onuma Y, et al. First serial assessment at 6 months and 2 years of the second generation of absorb everolimuseluting bioresorbable vascular scaffold: a multi-imaging modality study. Circ Cardiovasc Interv. 2012;5(5):620-632.

126. Diletti R, Serruys PW, Farooq V, et al. ABSORB II randomized controlled trial: a clinical evaluation to compare the safety, efficacy, and performance of the Absorb everolimus-eluting bioresorbable vascular scaffold system against the XIENCE everolimus-eluting coronary stent system in the treatment of subjects with ischemic heart disease caused by de novo native coronary artery lesions: rationale and study design. Am Heart J. 2012;164(5):654-663.

127. Serruys PW, Chevalier B, Dudek D, et al. A bioresorbable everolimuseluting scaffold versus a metallic everolimus-eluting stent for ischaemic heart disease caused by de-novo native coronary artery lesions (ABSORB II): an interim 1-year analysis of clinical and procedural secondary outcomes from a randomised controlled trial. Lancet 2015;385(9962):43-54.

128. No authors listed. First-year results of CABRI (Coronary Angioplasty versus Bypass Revascularisation Investigation). CABRI Trial Participants. Lancet. 1995;346(8984):1179-1184.

129. No authors listed. Coronary angioplasty versus coronary artery bypass surgery: the Randomized Intervention Treatment of Angina (RITA) trial. Lancet. 1993;341(8845):573-580.

130. King SB 3rd, Lembo NJ, Weintraub WS, et al. A randomized trial comparing coronary angioplasty with coronary bypass surgery. Emory Angioplasty versus Surgery Trial (EAST). N Engl J Med. 1994; 331(16):1044-1050.

131. Hamm CW, Reimers J, Ischinger T, Rupprecht HJ, Berger J, Bleifeld W. A randomized study of coronary angioplasty compared with bypass surgery in patients with symptomatic multivessel coronary disease. German Angioplasty Bypass Surgery Investigation (GABI). N Engl J Med. 1994;331(16):1037-1043.

132. Puel J, Karouny E, Marco F, et al. Angioplasty versus surgery in multivessel disease: immediate results and in-hospital outcome in a randomised prospective study. Circulation. 1992;86 (Suppl 1):372.

133. Rodriguez A, Boullon F, Perez-Balino N, Paviotti C, Liprandi MI, Palacios IF. Argentine randomized trial of percutaneous transluminal coronary angioplasty versus coronary artery bypass surgery in multivessel disease (ERACI): in-hospital results and 1-year follow-up. ERACI Group. J Am Coll Cardiol. 1993;22(4):1060-1067.

134. BARI Investigators. The final 10-year follow-up results from the BARI randomized trial. J Am Coll Cardiol. 2007;49(15):1600-1606.

135. Serruys PW, Unger F, Sousa JE, et al. Comparison of coronary-artery bypass surgery and stenting for the treatment of multivessel disease. N Engl J Med. 2001;344(15):1117-1124.
136. Rodriguez A, Bernardi V, Navia J, et al. Argentine Randomized Study: Coronary Angioplasty with Stenting versus Coronary Bypass Surgery in patients with Multiple-Vessel Disease (ERACI II): 30-day and oneyear follow-up results. ERACI II Investigators. J Am Coll Cardiol. 2001;37(1):51-58.

137. SoS Investigators. Coronary artery bypass surgery versus percutaneous coronary intervention with stent implantation in patients with multivessel coronary artery disease (the Stent or Surgery trial): a randomised controlled trial. Lancet. 2002;360(9338):965-970.

138. Morrison DA, Sethi G, Sacks J, et al. Percutaneous coronary intervention versus coronary artery bypass graft surgery for patients with medically refractory myocardial ischemia and risk factors for adverse outcomes with bypass: a multicenter, randomized trial. Investigators of the Department of Veterans Affairs Cooperative Study \#385, the Angina With Extremely Serious Operative Mortality Evaluation (AWESOME). J Am Coll Cardiol. 2001;38(1):143-149.

139. Serruys PW, Ong AT, Morice MC, et al. Arterial Revascularisation Therapies Study Part II - Sirolimus-eluting stents for the treatment of patients with multivessel de novo coronary artery lesions EuroIntervention. 2005;1(2):147-156.

140. Rodriguez AE, Maree AO, Mieres J, et al. Late loss of early benefit from drug-eluting stents when compared with bare-metal stents and coronary artery bypass surgery: 3 years follow-up of the ERACI III registry. Eur Heart J. 2007;28(17):2118-2125.

141. Serruys PW, Morice MC, Kappetein AP, et al. Percutaneous coronary intervention versus coronary-artery bypass grafting for severe coronary artery disease. N Engl J Med. 2009;360(10):961-972.

142. Farkouh ME, Domanski M, Sleeper LA, et al. Strategies for multivessel revascularization in patients with diabetes. $N$ Engl J Med. 2012 367(25):2375-2384.

143. Serruys PW, Onuma Y, Garg S, et al. 5-year clinical outcomes of the ARTS II (Arterial Revascularization Therapies Study II) of the sirolimus-eluting stent in the treatment of patients with multivessel de novo coronary artery lesions. J Am Coll Cardiol. 2010;55(11) 1093-1101.

144. Mohr FW, Morice MC, Kappetein AP, et al. Coronary artery bypass graft surgery versus percutaneous coronary intervention in patients with three-vessel disease and left main coronary disease: 5-year follow-up of the randomised, clinical SYNTAX trial. Lancet 2013;381(9867):629-638.

145. Bangalore S, Toklu B, Feit F. Outcomes with coronary artery bypass graft surgery versus percutaneous coronary intervention for patients with diabetes mellitus: can newer generation drug-eluting stents bridge the gap? Circ Cardiovasc Interv. 2014;7(4):518-525.

146. Campos CM, Christiansen EH, Stone GW, Serruys PW. The EXCEL and NOBLE trials: similarities, contrasts and future perspectives for left main revascularisation. EuroIntervention. 2015;11 Suppl V: V115-V119.

147. Garcia S, Sandoval Y, Roukoz H, et al. Outcomes after complete versus incomplete revascularization of patients with multivessel coronary artery disease: a meta-analysis of 89,883 patients enrolled in randomized clinical trials and observational studies. J Am Coll Cardiol. 2013; 62(16):1421-1431

Research Reports in Clinical Cardiology

\section{Publish your work in this journal}

Research Reports in Clinical Cardiology is an international, peerreviewed, open access journal publishing original research, reports, editorials, reviews and commentaries on all areas of cardiology in the clinic and laboratory. The manuscript management system is completely online and includes a very quick and fair peer-review system.

\section{Dovepress}

Visit http://www.dovepress.com/testimonials.php to read real quotes from published authors. 